\author{
Justyna Starzyk, Anna Such, Dominika Drab, ElżBieta Kolaczkowska \\ Pracownia Hematologii Eksperymentalnej \\ Instytut Zoologii $i$ Badań Biomedycznych \\ Uniwersytet Jagielloński \\ Gronostajowa 9, 30-387 Kraków \\ E-mail: ela.kolaczkowska@uj.edu.pl
}

\title{
SARS-CoV-2 A NEUTROFILE: W SIECI NEUTROFILOWYCH PUŁAPEK ZEWNĄTRZKOMÓRKOWYCH NET
}

\section{WSTEP}

Wirus SARS-CoV-2 stanowi poważne zagrożenie dla funkcjonowania płuc, a także innych narząów, w tym nerek, wątroby i serca, oraz śródbłonków naczyń krwionośnych, prowadzac nawet do śmierci zakażonego pacjenta. U osób, u których rozwija się choroba COVID-19 (ang. coronavirus disease 2019), dochodzi do rozregulowania zarówno wrodzonej, jak i nabytej odpowiedzi immunologicznej oraz balansu pomiędzy nimi. Choć ciagle poznajemy mechanizmy tej choroby, wiadomo już, że jedna $z$ najważniejszych przyczyn procesów patofizjologicznych zachodzacych u chorych jest hiper-aktywacja neutrofili, prowadzaca do nadmiernego wyrzutu neutrofilowych sieci zewnattrzkomórkowych (NET), które nie sa prawidłowo usuwane. Rola NET jest wyłapywanie patogenów takich jak wirusy czy bakterie, ale moga one stanowić miecz obosieczny, prowadzac także do uszkodzeń tkanek własnych. Wynika to $z$ faktu, że proteazy wchodzace w skład NET, takie jak elastaza neutrofilowa, moga ułatwiać wnikanie wirusa do komórek (ułatwiaja remodelling białek powierzchniowych wirusa), sprzyjaja tworzeniu zakrzepów, a także aktywacji układu dopełniacza. $\mathrm{Na}$ początku 2021 r. grupa 47 naukowców zajmujących się badaniami NET, w tym współautorka obecnego opracowania (EK), zebrali i przeanalizowali wszystkie doniesienia na temat powiązań pomiędzy pułapkami neutrofilowymi a przebiegiem infekcji SARS-CoV-2, wykazując ścisłą zależność po- między nimi (ACKERMANN i współaut. 2021). W obecnej pracy charakteryzujemy NET oraz opisujemy ich rolę $\mathrm{w}$ rozwoju i przebiegu infekcji COVID-19. Przedstawiamy także testowane i potencjalne terapie anty-NET, mogace poprawić stan chorych i/lub ochronić przed śmiercią pacjentów.

\section{NEUTROFILE}

Neutrofile to komórki układu odpornościowego, biorace udział w odpowiedzi wrodzonej, nazywane inaczej granulocytami obojętnochłonnymi lub leukocytami polimorfonuklearnymi (ang. polymorphonuclear leukocytes, PMN), które stanowią pierwsza linię obrony organizmu przed patogenami (KolaCZKOWSKA i KUBES 2013). W krwiobiegu człowieka neutrofile stanowia większość wszystkich leukocytów (50-70\%), a w zdrowym organizmie, w ciagu doby, powstaje ich ok. $10^{11}$ (BORREGAARD 2010). Wartości referencyjne prawidłowej liczebności neutrofili wahają się między $1800-8000 / \mu 1$ krwi zdrowego, dorosłego człowieka. Dojrzałe granulocyty obojętnochłonne krążące w krwiobiegu maja średnicę 10-15 $\mu \mathrm{m}$, jadro podzielone na segmenty oraz unikatowe ziarnistości i pęcherzyki wydzielnicze obecne w cytoplazmie (BORREGAARD 2010). Obecnie uważa się, że długość życia neutrofili we krwi obwodowej człowieka to ok. 24 godziny, ale $\mathrm{w}$ tkankach, podczas zapalenia, czas ten może ulec wydłużeniu (KoLACZKOWSKA i KUBES 2013). 
Proces powstawania granulocytów, w tym neutrofili, nazywamy granulocytopoezą. Zachodzi on w szpiku kostnym, gdzie neutrofile różnicuja się $z$ komórek macierzystych krwiotworzenia (BORREGAARD 2010). Kolejne stadia dojrzewajacych neutrofili to mieloblast, promielocyt, mielocyt, metamielocyt, neutrofil pałeczkowaty i neutrofil polimorfojądrowy (GOLAB i współaut. 2017). Granulocyty obojętnochłonne uwalniane sa ze szpiku do krwi, i choć zasadniczo w stanie homeostazy neutrofile występuja wyłącznie w krwiobiegu, to jednak pewna ich pulę można odnaleźć w szpiku kostnym, śledzionie, watrobie i płucach (SUMMERS i współaut. 2010). W narząach tych spełniaja one rolę komórek patrolujaccych, monitorując obecność patogenów lub uszkodzeń tkanek (KOLACZKOWSKA i KuBES 2013). Dodatkowo, w krwiobiegu, oprócz krążących neutrofili, istnieje też tzw. pula marginalna; sa to neutrofile, które pozostaja $\mathrm{w}$ kontakcie $\mathrm{z}$ śródbłonkiem żyłek pozawłosowatych (GOLAB i współaut. 2017). Komórki te zostaja zrekrutowane (wracaja do puli krażącej we krwi) dopiero pod wpływem bodźców zapalnych (KolAczKowsKA i KUBES 2013).

\section{UNIKATOWE CECHY NEUTROFILI}

Morfologicznie neutrofile posiadaja dwie charakterystyczne cechy: segmentowane jadro komórkowe i liczne, zróżnicowane ziarnistości (Ryc. 1).

Płatowate, segmentowane jądro neutrofila w dojrzałej komórce składa się z 3 do 5 płatów, a ich liczba zwiększa się w miarę dojrzewania neutrofila. Jednak spotykane sa przypadki, w których jądro neutrofila posiada więcej płatów i takie zjawisko zwane jest hipersegmentacją (MANLEY i współaut. 2018). Jest to stan patologiczny, najczęściej spowodowany niedoborem składników odżywczych, takich jak witamina $\mathrm{B}_{12}$, kwas foliowy czy żelazo (GOlAB i współaut. 2017). Mimo swoich dużych rozmiarów, jądro nie jest elementem statycznym. Dzięki swojemu położeniu w sąsiedztwie centrum organizującego mikrotubule (ang. microtubule organizing centre, MTOC) może ułatwiać przemieszczanie się komórki. MTOC odpowiada za skupienie mikrotubul, które rozgałęziaja się wewnatrz komórki, otaczajac także jądro komórkowe (MANLEY i współaut. 2018). W MTOC generowane sa siły zdolne popchnać jadro neutrofila do przodu, co skutkuje ruchem całej komórki. Z kolei dzięki swoje$\mathrm{mu}$ unikatowemu składowi, jądro może dynamicznie zmieniać kształt, kiedy komórka przeciska się pomiędzy komórkami śródbłonka opuszczając naczynie (MANLEY i współaut. 2018). Zatem odkształcalność jądra może

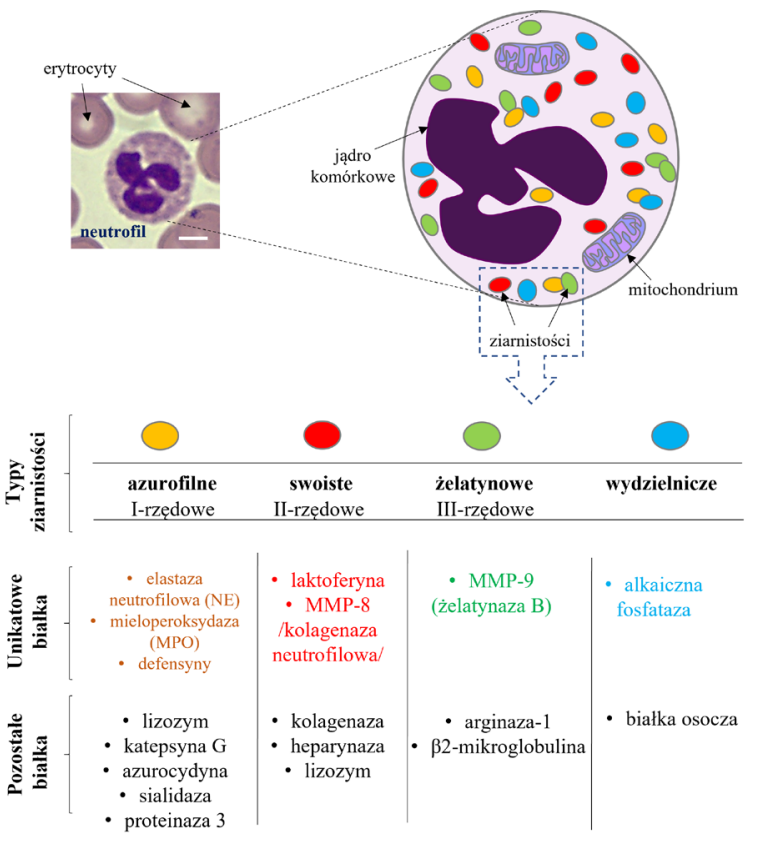

Ryc. 1. Schematyczna budowa neutrofila: unikatowe jądro i typy ziarnistości.

$\mathrm{Na}$ rycinie przedstawiono schematyczna budowę neutrofila $z$ uwzględnieniem segmentowanej struktury jądra komórkowego oraz licznych ziarnistości czterech typów. Dla każdego typu ziarnistości wymieniono najważniejsze unikatowe białka, specyficzne tylko dla danego typu ziarnistości, a także pozostałe białka $\mathrm{w}$ nich występujące. Na schemacie zaznaczono także obecność mitochondriów, które choć nieliczne w neutrofilach, maja znaczenie $\mathrm{w}$ procesach przedstawionych na Ryc. 3. Dla porównania, schemat neutrofila zestawiono ze zdjęciem ludzkiego neutrofila, obecnego w rozmazie ludzkiej krwi pełnej (barwienie May-Grunwald Giemsa; skala $5 \mu \mathrm{m}$, autorka: dr Małgorzata Opydo-Chanek). Na zdjęciu widoczne sa także fragmenty erytrocytów. MMP - metaloproteinaza macierzy zewnątrzkomórkowej.

narzucać szybkość migracji neutrofili, będacc kluczowym elementem determinujacym efektywność tego zjawiska.

Kolejna unikatowa cecha neutrofili sa ich ziarnistości występujace $\mathrm{w}$ czterech typach: ziarnistości pierwszorzędowe (azurofilne), drugorzędowe (swoiste, wtórne), trzeciorzędowe (żelatynowe) i pecherzyki wydzielnicze, a każdy $z$ nich różni się składem białek przeciwbakteryjnych i enzymatycznych, wykorzystywanych do walki $z$ patogenami (GolaB i współaut. 2017) (Ryc. 1). Przykładowo, w ziarnistościach azurofilnych przechowywane sa m.in. mieloperoksydaza (MPO) czy elastaza neutrofilowa (GoLAB i współaut. 2017).

\section{JAK FUNKCJONUJA NEUTROFILE?}

Neutrofile, jak i inne leukocyty odpowiedzi wrodzonej, rozpoznaja patogeny (ich 
unikatowe struktury) poprzez receptory rozpoznajace wzorce (ang. pattern recognition receptors, PRR), które moga występować zarówno na powierzchni, jak i w strukturach wewnątrzkomórkowych leukocytów (GolaB i współaut. 2017). Przykładem takich struktur sa receptory Toll-podobne (ang. Toll-like receptors, TLR) wystepujace w licznych podtypach, np. TLR2 czy TLR4, zlokalizowane na powierzchni leukocytów. Receptory PRR rozpoznaja wzorce molekularne zwiazane $z$ patogenami (ang. pathogen associated molecular patterns, PAMP), struktury niezbędne dla patogenów do ich przeżycia lub namnażania, i jednocześnie nieobecne na/w komórkach kręgowców. Do PAMP należy m.in. lipopolisacharyd (LPS), peptydoglikany, kwas tejchojowy i mannany (Golab i współaut. 2017). Poszczególne PRR rozpoznaja dane PAMP, np. TLR4 rozpozna-
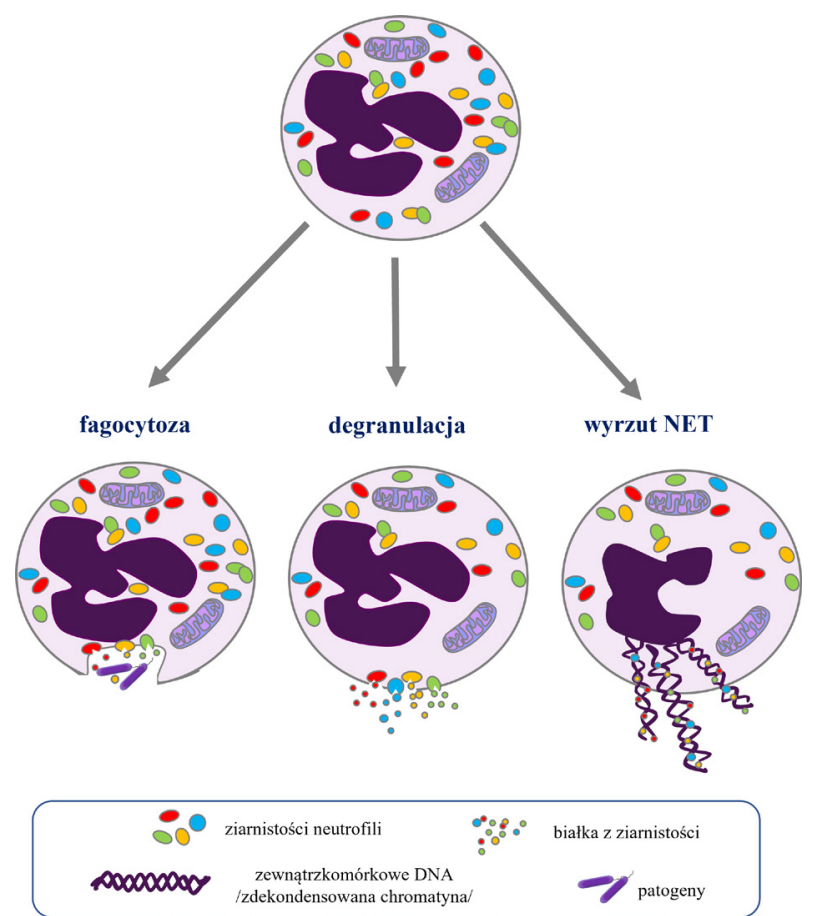

Ryc. 2. Mechanizmy eliminacji patogenów przez neutrofile.

W procesie fagocytozy mikroorganizmy sa pochłaniane do wnętrza komórki na zasadzie endocytozy, a następnie trawione przez enzymy i białka znajdujace się we wnętrzu ziarnistości lub $z$ wykorzystaniem reaktywnych form tlenu o silnej toksyczności dla patogenów (wybuch tlenowy). Degranulacja polega na uwolnieniu ziarnistości lub ich zawartości do przestrzeni międzykomórkowej, a wydzielone białka neutralizuja patogeny $\mathrm{w}$ otoczeniu komórki. Wyrzut zewnątrzkomórkowych pułapek neutrofilowych (NET) następuje w wyniku m.in. aktywności białek pochodzacych $\mathrm{z}$ ziarnistości, a liczne $\mathrm{z}$ tych białek sa także przyłączone do sieci. To właśnie one uczestniczą w eliminacji patogenów złapanych w NET. NET - zewnatrzkomórkowe pułapki neutrofilowe (wg KoLACZKOWSKA i KUBES 2013, zmodyfikowana). je LPS, a TLR2 kwasy tejchojowe. Istnieja także podtypy receptorów TLR zlokalizowane wewnątrzkomórkowo, np. TLR7 i TLR9, odpowiedzialne za rozpoznanie określonego typu kwasów nukleinowych, odpowiednio ssRNA (ang. single stranded RNA) i DNA wirusów (GOLAB i współaut. 2017). Rozpoznanie patogenu prowadzi do aktywacji neutrofili, które moga eliminować je na trzy główne sposoby: poprzez fagocytozę, degranulację i zewnattrzkomórkowe pułapki neutrofilowe (BORREGAARD 2010) (Ryc. 2).

Fagocytoza to proces, który polega na endocytozie (aktywnym pochłanianiu) mikroorganizmów, a następnie ich wewnattrzkomórkowym zabijaniu (GOLAB i współaut. 2017). W procesie niezależnym od tlenu wykorzystywane sa enzymy (np. lizozym), białka bakteriobójcze (np. laktoferyna) i kationowe peptydy (np. defensyny), które znajdują się w ziarnistościach neutrofili (GoLAB i współaut. 2017). Po połączeniu ziarnistości i fagosomu, do wnętrza powstałego pęcherzyka dostaja się wysokie stężenia powyższych substancji, które sa toksyczne dla patogenów (WITKO-SARSAT i DESCAMPS-LATSCHA 1994). Należy zaznaczyć, że składniki ziarnistości, działając synergistycznie, daja znacznie silniejszy efekt, niż działajac pojedynczo (GolAB i współaut. 2017). Z kolei proces zależny od tlenu wymaga użycia reaktywnych form tlenu (ang. reactive oxygen species, ROS) $i$ jest nazywany wybuchem tlenowym (KoLACZKOWSKA i współaut. 2007). Do produkcji ROS niezbędna jest oksydaza NADPH (ang. NADPH oxidase, Nox). Jest to wieloskładnikowy kompleks enzymatyczny, który umiejscowiony jest w błonie fagosomu (BORREGAARD 2010). ROS sa zwiazkami wysoce toksycznymi, działajacymi na bakterie, grzyby, pasożyty i komórki zmienione nowotworowo (GOLAB i współaut. 2017). Aby zabezpieczyć zdrowe komórki organizmu i same neutrofile przed szkodliwym działaniem ROS, reaktywne formy tlenu sa poddawane unieczynnieniu przez enzymy takie jak: dysmutaza ponadtlenkowa, katalaza oraz reduktaza i peroksydaza glutationowa (GolAB i współaut. 2017).

Ziarna neutrofili w całości lub tylko ich zawartość, moga być również wydzielane na zewnątrz komórek, a proces ten nazywamy degranulacją. Dzięki temu enzymy i białka wypełniające ziarnistości moga działać na patogeny zlokalizowane w płynach ustrojowych i tkankach (BORREGAARD 2010).

Ostatni mechanizm eliminacji patogenów to tworzenie NET omówione w osobnym, kolejnym rozdziale, a proces ten także wykorzystuje białka zmagazynowane w ziarnistościach neutrofili. 


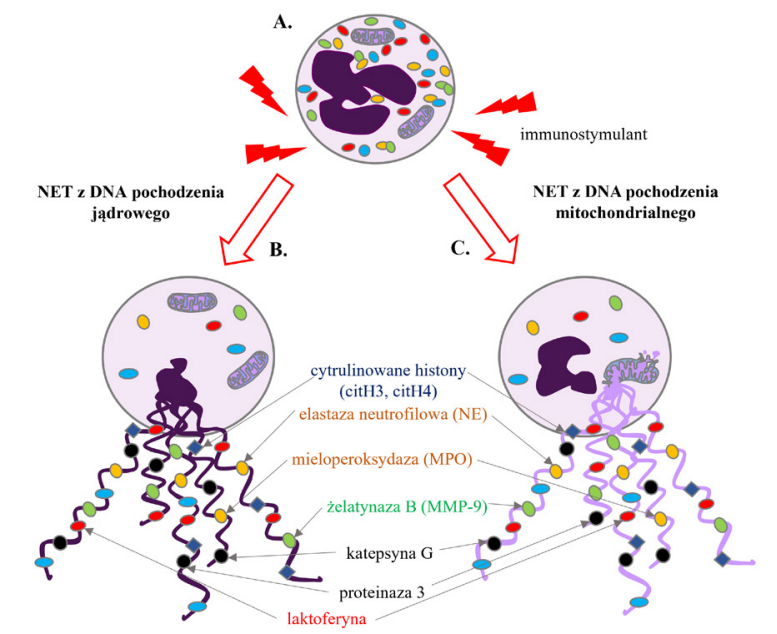

D.
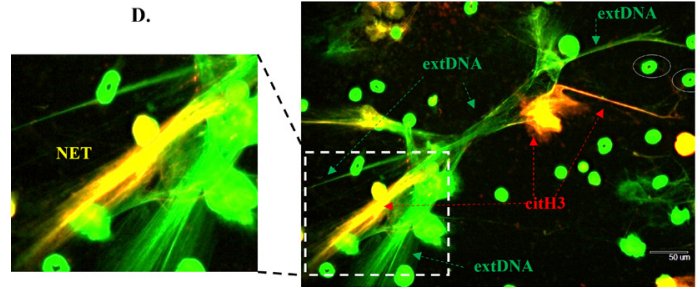

Ryc. 3. Schematyczna budowa NET.

Neutrofilowe pułapki zewnatrzkomórkowe składają się ze zdekondensowanego DNA wyrzuconego na zewnatrz komórki w postaci włókien chromatyny, do którego przyłączone sa białka jadrowe - cytrulinowane histony (citH3/4) i białka obecne w ziarnistościach neutrofila, takie jak elastaza neutrofilowa (NE), mieloperoksydaza (MPO), katepsyna G, żelatynaza B (MMP-9) czy proteinaza 3. Neutrofile (A) wyrzucaja NET pod wpływem silnej aktywacji, ale ich szkielet (DNA) może pochodzić albo $\mathrm{z}$ jądra (B) albo $z$ mitochondriów (C). (D) Zdjęcie pokazuje rzeczywisty wygląd NET, z DNA pochodzenia jądrowego, wyrzuconych przez neutrofile myszy laboratoryjnych pod wpływem lipopolisacharydu (mikroskopia konfokalna, skala $50 \mu \mathrm{m})$. Wybarwiono dwie składowe NET: citH3 (kolor czerwony) i extDNA (kolor zielony). Miejsca kolokalizacji (nakładania się) tych dwóch sygnałów (kolor żółty) ostatecznie potwierdzają obecność NET (autorka zdjęcia: mgr Iwona Cichoń). extDNA - zewnatrzkomórkowe DNA.

\section{NET: NEUTROFILOWE SIECI ZEWNĄTRZKOMÓRKOWE}

Neutrofilowe sieci zewnattrzkomórkowe (ang. neutrophil extracellular traps, NET) to nieobłonione struktury zbudowane m.in. $z$ DNA, które ma postać włókien o średnicy 15-17 nm oraz domen globularnych o średnicy $25 \mathrm{~nm}$ (BRINKMANN i współaut. 2004). Składowe te łącza się, tworzac nici DNA o średnicy do $50 \mathrm{~nm}$. DNA stanowi szkielet NET, do którego przyłączone sa białka pochodzace $z$ ziarnistości pierwszorzędowych (np. elastaza neutrofilowa, mieloperoksydaza, katepsyna G), drugorzędowych (np. laktoferyna) i trzeciorzędowych (np. żelatynaza B) neutrofili, oraz wszystkie typy histonów: H1, H2A, H2B, H3 i H4 (BRINKMANN i współaut. 2004) (Ryc. 3). DNA, posiadające ujemny ładunek elektryczny, wiaże pozostałe naładowane dodatnio elementy NET (KOLACZKOWSKA i współaut. 2015).

Spośród znanych mechanizmów powstawania NET, poniżej opisano dwa główne, które będa istotne w kontekście infekcji SARS-CoV-2. Pierwszy $z$ nich wiaże się $z$ aktywnościa elastazy neutrofilowej (NE), proteazy serynowej (rozkładającej wiąania peptydowe w białkach; zawierajacej w centrum aktywnym aminokwas serynę), która zatem jest nie tylko elementem składowym NET, ale także uczestniczy $\mathrm{w}$ ich tworzeniu. Wykazano, że po aktywacji neutrofila, NE przemieszcza się $z$ ziarnistości azurofilnych do jądra komórkowego, gdzie enzymatycznie degraduje (rozkłada) histony typu 1 (H1), które utrzymuja zwarta strukturę chromatyny (PAPAYANNOPOULOS i współaut. 2010). W ten sposób zapoczatkowana jest dekondensacja chromatyny, a w proces ten zaangażowane jest także inne białko $\mathrm{z}$ ziarnistości neutrofili - MPO, choć nie znamy szczegółów jego działania. MPO jest jednym $z$ enzymów zaangażowanych $\mathrm{w}$ produkcję ROS zależna od oksydazy NADPH i choć w trakcie tworzenia NET mieloperoksydaza działa w sposób niezależny od swojej aktywności enzymatycznej [tylko brak białka (myszy nokaut), a nie samo zahamowanie aktywności MPO, hamuje powstanie NET], to wykazano, że ROS moga pomagać NE wydostać się $z$ ziarnistości (PAPAYANNOPOULOS i współaut. 2010). Drugim procesem wspomagajacym dekondensacje chromatyny jest cytrulinacja histonów, będąca konsekwencją aktywacji deiminazy peptydyloargininy 4 (ang. peptidylarginine deiminase 4, PAD4). Enzym ten jest zlokalizowany w jąrze komórkowym, m.in. leukocytów, a jego aktywacja jest zależna od dostępności jonów wapnia $\mathrm{Ca}^{2+}$. (VossenaAr i współaut. 2003). Poziom tych ostatnich wzrasta po aktywacji neutrofili i jest także niezbędny dla wyrzutu NET (GUPTA i współaut. 2014). PAD4 odpowiada za zastapienie w resztach histonów H2A, H3 i H4 aminokwasu argininy przez cytrulinę, co powoduje zmianę ladunku pozytywnie naładowanej argininy na neutralna cytrulinę (WANG i współaut. 2009). Wykazano to m.in. stosujac inhibitory PAD4, takie jak Cl-amidine. Należy zaznaczyć, że zarówno NE, PAD4, a zwłaszcza ROS nie zawsze sa zaangażowane w tworzenie NET.

Nie wiemy dokładnie $z$ czego to wynika, ale postuluje się, że może to zależeć m.in. od stymulanta, czynnika indukującego powstanie NET (BOELTZ i współaut. 2019). NET moga się też różnić między sobą w 
kontekście pochodzenia DNA oraz przeżywalności neutrofili po ich uwolnieniu. Choć głównie opisuje się NET $z$ DNA pochodzenia jądrowego, wykazano także, że może ono pochodzić $z$ mitochondriów (ludzkie mitochondrium zawiera 4-10 kolistych cząsteczek DNA kodujących część białek łańcucha oddechowego) (YOUSEFI i współaut. 2009) (Ryc. 3). Kiedy komórka zostaje pozbawiona materiału genetycznego, zwłaszcza jądrowego, intuicyjnie wydaje się, że ginie. Jednak wykazano, że neutrofile moga przeżyć wyrzut NET, przemieszczać się i w ten sposób wyłapywać więcej patogenów oraz je fagocytować (YIPP i KuBES 2013). Znamy przykłady innych ludzkich komórek (erytrocyty) oraz elementów morfotycznych krwi (płytki), które całe swoje dojrzałe życie funkcjonuja bez jądra komórkowego, a zatem nie jest ono niezbędne. Jednak funkcjonowanie takiej komórki zależy od tego, jakie białka zostały w niej wyprodukowane i zmagazynowane zanim utraciła jądro, czy to w czasie rozwoju (erytrocyt, megakariocyt/płytka) czy po wyrzucie NET. Jeszcze nie wiemy czy w organizmie (badania prowadzi się głównie na izolowanych neutrofilach) większość neutrofili przeżywa wyrzut NET czy umiera, ale fakt pozostania przy życiu wydaje się zwiększać skuteczność działania neutrofili i ich NET. Te i inne mechanizmy tworzenia NET zostały opisane w artykule, który ukazał się w Kosmosie (SANTOCKI i KoŁACZKOWSKA 2017).

Neutrofile moga uwalniać NET pod wpływem różnych bodźców. Moga to być całe patogeny lub tylko ich fragmenty, które rozpoznawane sa jako PAMP, oraz struktury endogenne (własne). Dotychczas potwierdzono produkcje NET w odpowiedzi na bakterie, grzyby, pierwotniaki i wirusy (KAPLAN i RADIC 2012). Dodatkowo, w czasie procesów zapalnych toczacych się $w$ organizmie dochodzi do uszkodzenia/obumierania własnych komórek, z których wydostają się organelle komórkowe/DNA/elementy cytoszkieletu, które nazywamy strukturami molekularnymi zwiazanymi $z$ uszkodzeniem (ang. danger/damage associated molecular patterns, DAMP), poprzez analogię do PAMP. Ponieważ w prawidłowych warunkach (stan homeostazy) znajduja się one we wnętrzu komórek, ich eksternalizacja powoduje aktywację leukocytów, w tym neutrofili i m.in. wyrzut NET, alarmujac organizm o zagrożeniu. Tworzenie NET może być także zainicjowane przez mediatory zapalne i elementy odpowiedzi immunologicznej. Do tych pierwszych należą cytokiny i chemokiny, takie jak: czynnik martwicy nowotworów (ang. tumor necrosis factor $a, T N F-a)$, interleukina $1 \beta$ (IL-1 $\beta$ ), IL-8 czy interferon $\gamma$ (IFN- $\gamma)$, a do tych drugich: składnik układu dopełniacza C5a (Glo- sarium 1), przeciwciała, tlenek azotu (ang. nitric oxide, NO), produkowane w czasie reakcji zapalnej (KAPLAN i RADIC 2012).

Rolą zewnątrzkomórkowych pułapek neutrofilowych jest wyłapywanie i unieruchamianie patogenów, w tym wirusów, które przedostały się do organizmu, a dzięki wysokiemu miejscowemu stężeniu enzymów i białek przeciwbakteryjnych przyłaczonych do NET, także zabijanie złapanych mikroorganizmów. Patogeny uwięzione w NET niejednokrotnie zostaja zabite jeszcze zanim zacznie się proces fagocytozy, a ich możliwości rozprzestrzeniania się sa znacznie ograniczone (BRINKMANN i współaut. 2004). Dodatkowo, neutrofile moga przemieszczać się z przymocowanymi do nich NET, zwiększajac zasięg ich działania i potegując efekt hamowania infekcji (KolaczKOWsKA i KuBES 2013).

W celu wykrycia produkcji NET przez neutrofile człowieka można wykonać kilka typów analiz: można oznaczać je na skrawkach pobranych $z$ biopsji (zarówno pacjentów, jak i pośmiertnie) albo oznaczać tzw. markery NET we krwi. Markerami tymi sa najczęściej zewnątrzkomórkowe DNA lub proteazy, ale najwłaściwszym jest wykrywanie ich kompleksów (np. DNA-MPO, DNA-NE itd.), gdyż występując pojedynczo moga być pomylone, odpowiednio, $z$ nekroza komórek (umierające komórki rozpadają się i dochodzi do uwolnienia DNA) lub degranulacja neutrofili, kiedy to uwalniaja one proteazy i inne białka ze swoich ziarnistości (BOELTZ i współaut. 2019). Jako pojedynczy marker, przydatne moga być natomiast pomiary cytrulinowanych histonów (np. cytrulinowanego histonu H3, citH3), które obecnie uważa się za charakterystyczne dla NET.

Po spełnieniu swojej funkcji, NET sa najprawdopodobniej fagocytowane przez makrofagi, choć dotychczas takich obserwacji dokonano tylko $\mathrm{w}$ warunkach in vitro (SANTOCKI i KoŁACZKOWSKA 2017, 2020). Proces ten ułatwia działanie DNazy I (deoksyrybonukleazy), enzymu tnacego nici DNA na fragmenty, które sa w stanie pochłonać komórki żerne (FARRERA i FADEEL 2013). Udział w degradowaniu neutrofilowych pułapek zewnatrzkomórkowych ma również składnik układu dopełniacza C1q (Glosarium 1), który przyłączajac się do DNA i histonów, opsonizuje NET, wyznaczając je jako cel do zniszczenia przez makrofagi (FARRERA i FADEEL 2013).

\section{CIEMNA STRONA NET: AKTYWNOŚĆ PROTEAZ I ZEWNATRZKOMÓRKOWEGO DNA}

NET pełnia swoje funkcje w walce $z$ patogenami, jednak mechanizmy ich po- 
Glosarium 1 | Mechanizmy aktywacji układu dopelniacza w powiązaniu z SARS-CoV-2 i NET

Układ dopełniacza jest kluczowym mediatorem wrodzonej odpowiedzi immunologicznej - pełni rolę ochronną przed czynnikami zakaźnymi aktywując kaskadę reakcji o charakterze prozapalnym, uzupełniając tym samym funkcję efektorową przeciwciał w niszczeniu drobnoustrojów. W skład układu dopełniacza wchodzi około 40 białek (obecnych w osoczu i płynach ustrojowych; wiele $\mathrm{z}$ nich oznaczonych jest symbolem $\mathrm{C}$, od complement, i cyframi odpowiadającymi kolejności ich odkrycia). Białka te, aktywowane kaskadowo, uczestniczą m.in. w procesie opsonizacji (opłaszczania) patogenów, ich fagocytozie i/lub lizie, chemotaksji (ukierunkowanym napływie) do miejsca pojawienia się patogenu, czy też eliminacji uszkodzonych komórek własnych gospodarza. W zależności od rodzaju czynnika aktywującego, początkowe etapy tego procesu mogą przebiegać trzema różnymi drogami (alternatywną, lektynową oraz klasyczną). $\mathrm{Na}$ czerwono: symbolem * zaznaczono składowe aktywowane w czasie infekcji SARS-CoV-2, a symbolem strzałki, te których poziom wzrasta. $\Delta$ oznaczono te dodatkowo powiązane z obecnością NET u chorych na COVID-19. R - receptor, MAC kompleks atakujący błonę (powodujący lizę komórki), pozostałe skróty wyjaśnione w głównym tekście.

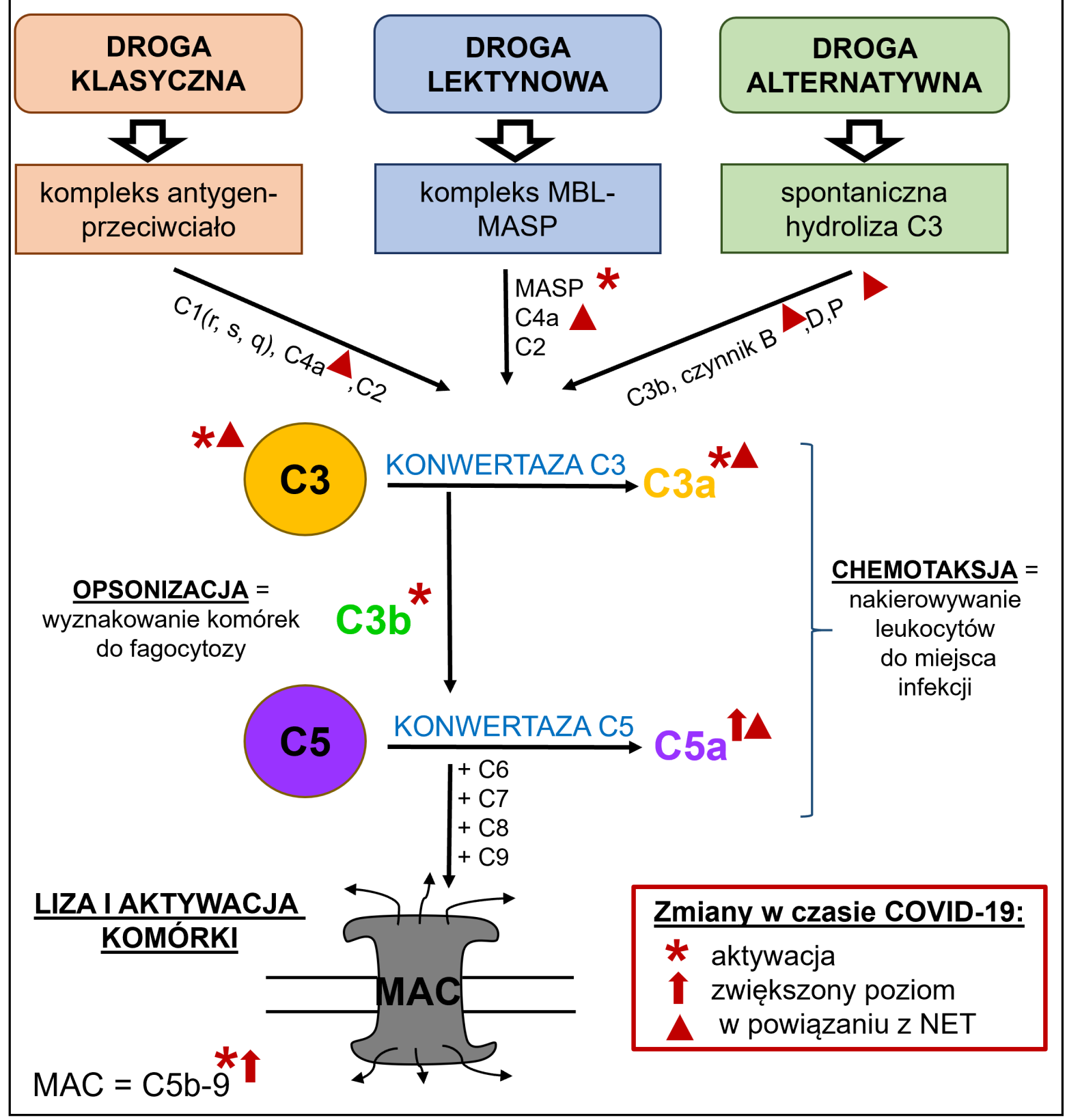


wstawania i degradacji nie sa niezawodne i całkowicie bezpieczne dla organizmu, niejednokrotnie prowadząc do pojawienia się niepożądanych skutków ubocznych (SANTOCKI i KOŁACZKOWSKA 2017, 2020). Negatywny wpływ NET potwierdzono dotychczas w stanach patologicznych/jednostkach chorobowych takich jak: sepsa, choroby autoimmunizacyjne (np. łuszczyca skóry czy toczeń rumieniowaty układowy), zespół ostrej niewydolności oddechowej (ang. acute respiratory distress syndrome, ARDS) oraz w licznych zaburzeniach krzepnięcia krwi, takich jak: zakrzepica żył głębokich (ang. deep vein thrombosis, DVT) czy układowe zapalenie małych naczyń (ang. small-vessel vasculitis, SVV) (ACKERMANN i współaut. 2021). Układ krzepnięcia to bardzo ważny zespół wzajemnie aktywujacych i dezaktywujacych się białek, który ma na celu stworzenie skrzepu i zahamowanie krwawienia, kiedy dojdzie do przerwania naczyń krwionośnych (potocznie: do krwawienia) (Glosarium 2). Jednak kiedy układ ten nie działa prawidłowo, albo jest nadmiernie aktywowany, moga powstawać lokalne skrzepy hamujace przepływ krwi i/ lub niszczace tkanki własne (SoRviLlo i współaut. 2019).

Zależność między NET a procesami nadmiernej koagulacji i tworzenia zakrzepów została rozpoznana wkrótce po ich odkryciu. Najpierw wykryto, że w niektórych przypadkach płytki krwi (trombocyty) sa wręcz niezbędne do zaktywowania neutrofili, stanowiąc niejako pomost pomiędzy bakteriami czy ich produktami a neutrofilami. W badaniach tych wykazano, że LPS bakteryjny może być w pierwszej kolejności rozpoznawany przez receptor TLR4, ale zlokalizowany na płytkach krwi, które następnie aktywuja neutrofile w nieznany jeszcze sposób (YIPP i KuBES 2013). Dzieje się tak, mimo że neutrofile również posiadaja receptory TLR4.

Ponadto, gdy NET zalegaja w naczyniach krwionośnych, moga przyłączyć się do nich płytki krwi i krwinki czerwone, a produkt takiego połaczenia to tzw. „czerwony skrzep”. Dodatkowo, $z$ powstała struktura może związać się czynnik von Willebranda (ang. von Willebrand factor, VWF) oraz fibronektyna i fibrynogen, które zwiększaja stabilność skrzepu (FUCHS i współaut. 2010) (Glosarium 2). Jeśli w układzie sercowo-naczyniowym znajdzie się wiele agregatów NET ze składnikami osocza, tzw. mikrozakrzepów, przepływ krwi będzie utrudniony, co może doprowadzić do niedokrwienia tkanki lub narządu (BRINKMANN i ZYCHLINSKY 2012).

Jak konkretnie NET wpływaja na aktywację układu krzepnięcia? Wykazano, że zwłaszcza NE i histony będące ważnymi elementami NET moga inicjować ten proces
(FUCHS i współaut. 2010). NE rozkłada inhibitor czynnika tkankowego TF (ang. tissue factor pathway inhibitor, TFPI), co prowadzi do uwolnienia zwiazanego $z$ nim czynnika Xa, prowadzac do aktywacji kolejnych czynników (Glosarium 2) (SoRvillo i współaut. 2019). Z kolei histony, zwłaszcza H3 i H4, sa rozpoznawane przez TLR2 i TLR4 na płytkach krwi aktywując je. Histon 4 może także uczestniczyć w aktywacji trombiny. Także inne elementy NET moga aktywować kaskadę krzepnięcia. Wykazano, że zewnątrzkomórkowy DNA krążacy we krwi aktywuje czynniki XII i XI kaskady krzepnięcia oraz wpływa na przebieg fibrynolizy (przeciwstawnego procesu majacego na celu usunięcie zakrzepu gdy nie jest on już potrzebny).

Także ze względu na fakt, że DNA objętościowo jest największą częścia NET, jest też jednym $z$ głównych składników skrzepu zainicjowanego przez pułapkę neutrofilowa, oprócz VWF i fibryny (SoRVILLo i współaut. 2019). Potwierdzaja to także badania, w których dodanie DNazy rozkładającej DNA częściowo ogranicza tworzenie skrzepu (FUCHS i współaut. 2010). Do NET przyłączają się też płytki krwi, tworza agregaty i stanowia platformę do powstania kolejnych mikrozakrzepów (MCDONALD i współaut. 2017). Ale składniki NET moga również powodować uszkodzenia tkanek własnych niezależnie od procesu krzepnieccia. Ponownie, odpowiedzialne sa za to te same składowe NET, NE oraz H3 i H4, które moga być bezpośrednio cytotoksyczne dla komórek śródbłonka naczyniowego (KoLACZKOWSKA i współaut. 2015).

Patologie zwiazane $z$ NET moga wynikać także $z$ faktu, że zawierają one w swojej strukturze DAMP (DNA, proteazy, histony itd.), przeciwko którym inicjowana jest reakcja zapalna, jako element odpowiedzi wrodzonej, ale także nabytej, $z$ zaangażowaniem limfocytów, w tym limfocytów B produkujących autoprzeciwciała skierowane przeciwko DAMP w NET (SANTOCKI i KOŁACZKOWSKA 2017, 2020). Rozróżniamy kilka grup takich przeciwciał. Pierwsza grupa jest skierowana przeciwko białkom obecnym na powierzchni NET (ang. anti-neutrophil cytoplasmic antibodies, ANCA), które charakteryzuja się wysokim powinowactwem do MPO i proteinazy 3 (FOUSERT i współaut. 2020). Immunoglobuliny te uważa się za jeden $z$ czynników prowadzących do rozwinięcia się u pacjenta SVV. ANCA moga pobudzać neutrofile do produkcji ROS i proteaz, co doprowadza do powstania stanów zapalnych w obrębie naczyń krwionośnych. Ponadto, ANCA moga stymulować neutrofile do wyrzutu NET zgodnie $z$ mechanizmem stężenia zwrotnego dodatniego - duża ilość NET doprowadza do 


\section{Glosarium 2 | Kaskady ukladu krzepnięcia w powiązaniu z infekcją SARS-CoV-2 i NET}

Wyróżniamy dwie kaskady krzepnięcia, (i) wewnątrzpochodną zainicjowaną przez czynnik XII oraz (ii) zewnątrzpochodną, w której inicjacji uczestniczy czynnik tkankowy (TF). (i) TF wydzielany jest przez komórki uszkodzonych tkanek, a następnie tworzy kompleks z czynnikiem VII aktywując czynnik IX, od tego miejsca oba szlaki się łączą. W wyniku następującej potem kaskady przemian dochodzi do aktywacji trombiny i powstania fibryny (włóknika), która tworzy rusztowanie skrzepu. (ii) szlak wewnątrzpochodny rozpoczyna się autokatalitycznej aktywacji czynnika XII, która jest zainicjowana przez kontakt, np. z odsłoniętym po uszkodzeniu naczynia kolagenem.

Obecność sieci NET w obrębie skrzepu powoduje aktywację czynnika XII (aktywowany bezpośrednio przez kontakt) i TF. Aktywowane są również trombina i fibrynogen, wiążące się do sieci NET. $Z$ kolei aktywna elastaza neutrofilowa (NE) obecna w NET, powoduje inaktywację inhibitora szlaku zależnego od czynnika tkankowego (TFPI) aktywując szlak zewnątrzpochodny. Ponadto sieci NET wiążą się z czynnikiem von Willebranda (VWF), który łączy się z czynnikiem VIII, chroniąc go przed degradacją. W ten sposób sieci NET przyczyniają się także do adhezji płytek krwi i tworzenia skrzepu.

$\mathrm{Na}$ schemacie na czerwono zaznaczono poszczególne elementy zaangażowane w kaskady krzepnięcia, a ulegające aktywacji w obecności sieci NET i ich składowych. Dodatkowo, symbolem *, zaznaczono składowe aktywowane $\mathrm{w}$ czasie infekcji SARS-CoV-2, a symbolem ${ }^{\wedge}$, te dodatkowo powiązane $\mathrm{z}$ obecnością NET u chorych na COVID-19.

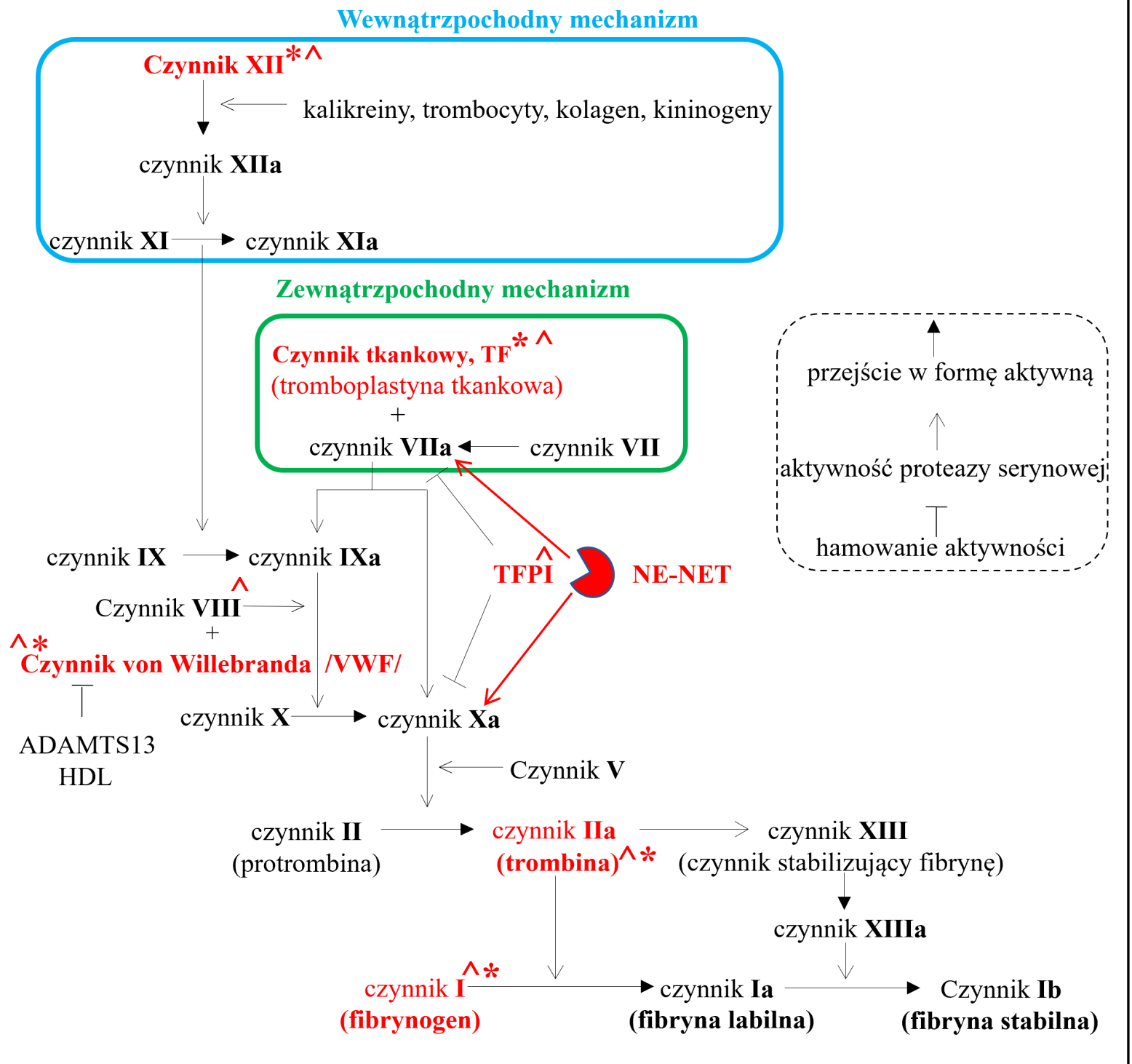




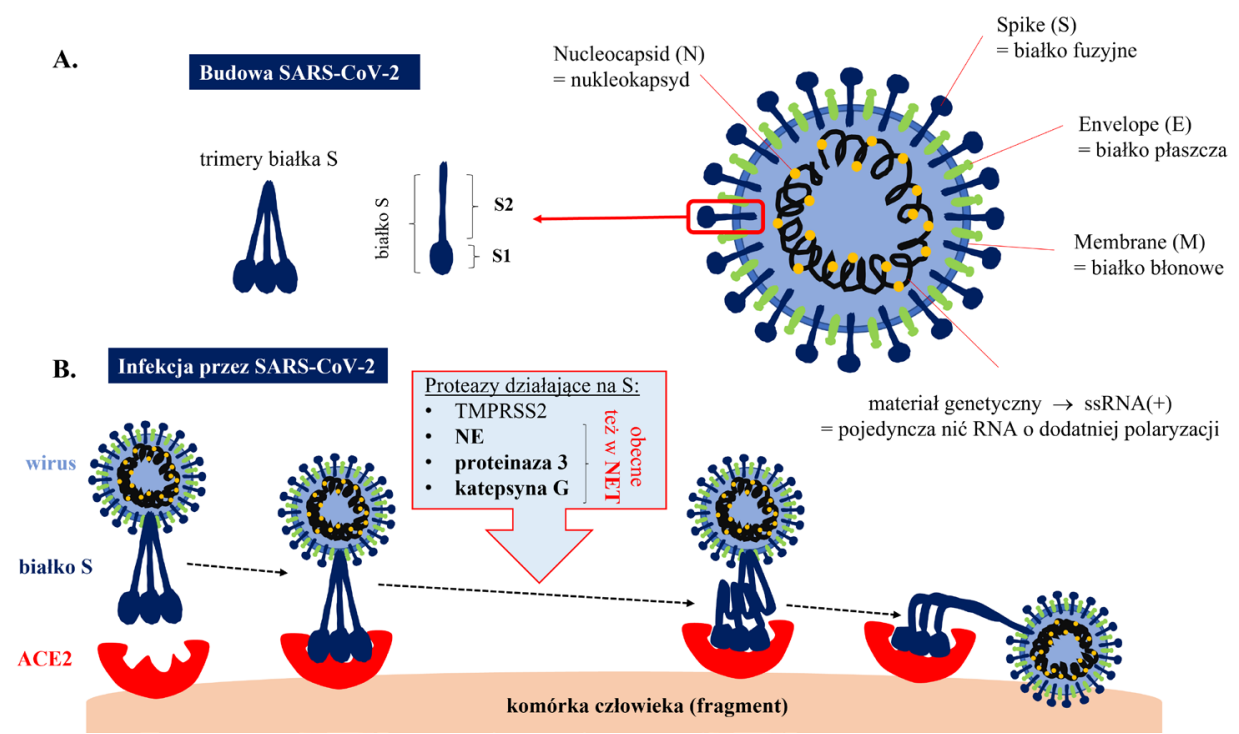

Ryc. 4. Budowa SARS-CoV-2 i mechanizm infekcji komórki w powiąaniu $z$ aktywnościa proteaz obecnych w neutrofilowych sieciach zewnątrzkomórkowych (NET).

(A) schematyczna budowa wirusa $\mathrm{z}$ naciskiem na białko fuzyjne $\mathrm{S}$ i obecność jego dwóch podjednostek, S1 i S2, połączonych kowalencyjnie. Proteolityczna aktywność enzymów powoduje, że choć pozostają połączone niekowalencyjnie, maja większa elastyczność, co umożliwia wirusowi fuzję z błoną komórki (na podstawie HuANG i współaut. 2020). ACE2 - konwertaza angiotensyny typu 2, TMPRSS2 - transbłonowa proteaza serynowa typu 2, NE - elastaza neutrofilowa.

pojawienia się wysokiego miana ANCA, które wywołują większą produkcję NET (SKOPELJA-GARDNER i współaut. 2018). Druga grupa to przeciwciała przeciwjacdrowe (ang. anti-nuclear antibodies, ANA) wiążace struktury znajdujace się w obrębie jądra komórkowego. Należą do nich DNA, histony czy centromer (KUMAR i współaut. 2009). ANA przyczyniaja się do wystapienia patologii w przebiegu wielu chorób autoimmunologicznych, m.in. w trakcie tocznia rumieniowatego układowego (KUMAR i współaut. 2009).

Ważnym komponentem sieci neutrofilowych sa histony poddane procesowi cytrulinacji, które również moga być celem autoprzeciwciał (ang. anti-citrullinated protein antibodies, ACPA). Obecność ACPA charakterystyczna jest dla pacjentów $z$ reumatoidalnym zapaleniem stawów. ACPA również stymuluja neutrofile do produkcji NET, które będac w przestrzeni maziowej stawów, pobudzaja komórki błony stawowej do wydzielania czynników prozapalnych (KHANDPUR i współaut. 2013).

\section{KONSEKWENCJE TWORZENIA NET W CZASIE INFEKCJI SARS-CoV-2}

NET POWSTAJA W CZASIE COVID-19

\section{KORELUJA Z ZAAWANSOWANIEM CHOROBY}

Dotychczas przedstawiłyśmy najważniejsze informacje o budowie i funkcjach NET, o najważniejszych mechanizmach ich tworzenia oraz o tym, jak moga uszkadzać nasze własne komórki i narządy. Informacje te były niezbędne, aby móc przedstawić skutki tworzenia NET w czasie infekcji SARS-CoV-2. Budowa i replikacja wirusa oraz przebieg i objawy wywoływanej przez niego choroby koronawirusowej COVID-19 zostały opisane w artykułach SANAKA oraz WIKOWSKIEGO i BRYL, w tym zeszycie KOSMOSU.

W tym miejscu chciałybyśmy przypomnieć tylko trzy fakty dotyczace SARS-CoV-2: (1) wirus posiada na swojej powierzchni białko błonowe S (Spike), które tworzy jego „koronę”, zawarta w nazwie tej grupy wirusów. Za pomocna białka S, wirus wiąze się $z$ (2) ACE2 na komórkach człowieka, a do zajścia tego procesu (3) niezbędna jest transbłonowa proteaza serynowa typu 2 (ang. transmembrane serine protease 2, TMPRSS2), także obecna na komórkach człowieka, oraz inne proteazy (Ryc. 4). Konwertaza angiotensyny typu 2 (ang. angiotensin converting enzyme 2, ACE2) występuje na powierzchni komórek człowieka, zwłaszcza zlokalizowanych w płucach, jelitach, sercu i nerkach (GuO i współaut. 2020). ACE2 jest enzymem katalizujacym rozkład angiotensyny II, która jest jednym z czynników w układzie renina-angiotensyna-aldosteron, odpowiedzialnym m.in. za regulację ciśnienia krwi (LI i współaut. 2020). Wniknięcie SARS-CoV-2 do komórki żywiciela 
wymaga działalności TMPRSS2 (HOFFMANN i współaut. 2020). Białko S występuje w formie trimerów, $z$ których każdy składa się z podjednostek S1 i S2 (Ryc. 4) - pierwsza jest odpowiedzialna za zwiazanie się wirusa z ACE2, a druga za fuzję $z$ komórka człowieka (HOFFMANN i współaut. 2020, HUANG i współaut. 2020). TMPRSS2 jest odpowiedzialny za enzymatyczne cięcie pomiędzy S1 a S2, co umożliwia tej drugiej połączenie się $\mathrm{z}$ błona komórki gospodarza i uwolnienie materiału genetycznego SARS-CoV-2 do cytoplazmy, gdzie RNA ulega translacji (GuO i współaut. 2020). Dodatkowo, elastaza neutrofilowa (NE), proteinaza 3 i katepsyna G, $\mathrm{w}$ tym te przyłączone do NET, również moga modyfikować białko $\mathrm{S}$ na podobnej zasadzie (Hu i współaut. 2020). A zatem NET moga także bezpośrednio zwiększać intensywność infekcji komórek człowieka.

Neutrofile i NET zidentyfikowano we fragmentach płuc pacjentów z COVID-19 pobranych w czasie autopsji post mortem (MIDDLETON i współaut. 2020). Także w próbkach surowicy osób zainfekowanych SARS-CoV-2 odnotowano wyższy poziom wolnego pozakomórkowego DNA, kompleksów MPO-DNA i citH3, w porównaniu do kontroli (ZuO i współaut. 2020). Określono również zależności tych markerów względem standardowych badań laboratoryjnych wykonywanych w szpitalach, takich jak liczba neutrofili i płytek krwi, poziom białka C-reaktywnego (CRP), D-dimerów i dehydrogenazy mleczanowej. CRP jest białkiem produkowanym $\mathrm{w}$ wattrobie, którego poziom może wzrosnać nawet 1000-krotnie w czasie reakcji zapalnej, podczas gdy obecność dehydrogenazy mleczanowej oznacza uszkodzenie komórek (enzym powinien znajdować się wewnattrzkomórkowo, gdzie uczestniczy w procesach metabolicznych) (GolAB i współaut. 2017). Natomiast obecność D-dimerów (fragmentów fibryny powstajacych $\mathrm{w}$ procesie jej degradacji przez plazminę) jest wskaźnikiem zajścia procesu krzepnięcia. Wykazano dodatnia korelacje między poziomem wolnego pozakomórkowego DNA i wszystkimi wymienionymi powyżej testami klinicznymi (za wyjątkiem liczby płytek krwi) oraz między liczba kompleksów MPO-DNA i liczba neutrofili, a także między poziomem cytrulinowanego histonu H3 i liczba płytek krwi (ZUO i współaut. 2020). Ponadto dokonano porównania między pacjentami przechodzacymi COVID-19 w postaci lekkiej i ciężkiej. Chorzy wymagajacy wentylacji mechanicznej (respirator) charakteryzowali się wyższymi poziomami wolnego pozakomórkowego DNA i kompleksów MPO-DNA, ale nie odnotowano istotnej różnicy między obiema grupami w poziomie cytrulinowanego histonu H3 i liczbie neu- trofili (ZUO i współaut. 2020). W naczyniach krwionośnych płuc chorych zaobserwowano jednoczesne występowanie neutrofili $z$ citH3 i płytek krwi. Dodatkowo, we krwi pacjentów z COVID-19 wykryto wysokie poziomy agregatów neutrofili i płytek krwi, płytkowych czynników stymulujacych proces tworzenia NET oraz cytokin IL-6 i IL-8 (MIDDLETON i współaut. 2020).

Następnie udało się wyjaśnić część mechanizmów odpowiedzianych za tworzenie NET w czasie infekcji SARS-CoV-2, analizujac neutrofile wyizolowane $z$ krwi ludzkiej. Wykazano, że do ich powstania wymagana jest interakcja wirusa SARS-CoV-2 z ACE2 i TMPRSS2, które znajduja się na powierzchni tych komórek (VERAS i współaut. 2020). Pokazano to $\mathrm{w}$ doświadczeniu, w którym do neutrofili dodano SARS-CoV-2, a równocześnie podano przeciwciała neutralizujące/blokujace ACE2 (powoduja one, że z ACE2 nie może się już zwiazać białko $\mathrm{S}$ wirusa) oraz inhibitor TMPRSS2 (kamostat; inhibitor deaktywujący proteaze), co zahamowało wyrzut NET w odpowiedzi na wirusa. Eksperyment ten udowadnia znaczenie tych struktur w procesie infekcji. Ponadto, wyrzut NET pod wpływem SARS-CoV-2 można także zahamować używając inhibitora enzymu PAD-4, tj. Cl-amidyny, co pokazuje, że również w tym przypadku wymagana jest cytrulinacja histonów (VERAS i współaut. 2020). Stymulacja do wyrzutu NET przez SARS-CoV-2 jest przeprowadzana także $\mathrm{w}$ trakcie procesu jego replikacji wewnattrz komórki. Wykazano bowiem, że inhibitor polimerazy RNA (fumaran dizoproksylu tenofowiru), wykorzystywanej $\mathrm{w}$ trakcie wirusowej replikacji, hamuje uwalnianie NET przez neutrofile w obecności SARS-CoV-2 (VERAS i współaut. 2020).

Wiemy już, że infekcja wirusem SARS-CoV-2 doprowadza do niekontrolowanego wyrzutu NET przez neutrofile. Najczęstsze powikłania przy COVID-19 (ARDS, sepsa i niewydolność wielonarzadowa) sa wynikiem rozregulowanej odpowiedzi immunologicznej, obecności wysokich stężeń cytokin prozapalnych i mikrozakrzepów, za które moga być odpowiedzialne właśnie NET (MIDDLETON i współaut. 2020). Co więcej, parametrami wskazującymi na możliwość rozwinięcia się ciężkiej postaci COVID-19 jest podwyższona liczba neutrofili i obecność NET we krwi (MidDLETON i współaut. 2020, ZUO i współaut. 2020). Z kolei dowodem na rozregulowanie balansu pomiędzy odpowiedzia wrodzona i nabyta jest wysoki stosunek neutrofili (odpowiedź wrodzona) do limfocytów (odpowiedź nabyta) (ang. neutrophil-to-lymphocyte ratio, NLR). Jest to ważne, gdyż jeśli organizm nie zdoła wytworzyć odpowiedzi nabytej (=zaangażować limfocyty) wystar- 
czająco szybko, walką $z$ patogenem zostaje obarczona odpowiedź wrodzona, która może nie być wystarczająca do zwalczenia wirusa. Jednak walczac $z$ infekcja ulega ona bardzo silnej aktywacji, w wyniku czego może dochodzić do niekontrolowanej sekrecji cytokin prozapalnych i NET (TANG i współaut. 2020).

\section{NET A SZTORM CYTOKINOWY W CZASIE COVID-19}

W czasie COVID-19 może rozwinąć się bardzo niebezpieczne zjawisko, jakim jest sztorm cytokinowy. Jest to stan, kiedy w organizmie dochodzi do nadmiernej produkcji cytokin prozapalnych, które wykazuja się różnym zakresem aktywności biologicznej i pochodzeniem (Song i współaut. 2020). Najważniejsze cytokiny zaangażowane w sztorm cytokinowy to: interleukiny (np. IL-2, IL7, IL-10), chemokiny (np. białkowy chemoatraktant monocytów MCP-1, białko zapalne makrofagów MIP-1a), TNF- $\alpha$, interferony, czynniki stymulujace tworzenie kolonii (ang. colony-stimulating factor, CSF) i czynniki wzrostu, które można podzielić na czynniki o działaniu prozapalnym i przeciwzapalnym (Song i współaut. 2020). Większość tych cytokin i czynników silnie stymuluje neutrofile do syntezy NET (MEHER i współaut. 2018). Ponadto, niektóre rekrutuja kolejne leukocyty, przez co poziom zapalenia w organizmie rośnie i tworzy się sprzężenie zwrotne dodatnie (TANG i współaut. 2020). W przypadku sztormu cytokinowego, drogi odpowiedzi immunologicznej, w których wykorzystywane sa cytokiny, nakładaja się na siebie, a efekt końcowy determinowany jest przez specyficzne interakcje receptorów TLR i ich ligandów (Song i współaut. 2020). W przypadku COVID-19, jako główny mechanizm powstawania sztormu cytokinowego podejrzewa się m.in. mechanizm związany $z$ nadmierna aktywacją odporności wrodzonej (TANG i współaut. 2020). Przykładowo, wydzielana przez makrofagi IL-1 $\beta$ silnie stymuluje neutrofile do syntezy NET (MEHER i współaut. 2018), przez co w organizmie może utworzyć się sprzężenie zwrotnie dodatnie: NET $\rightarrow$ IL-1 $\rightarrow$ więcej NET $\rightarrow$ więcej IL-1 $\beta$, itd. (JANIUK i współaut. 2021) (Ryc. 5). Wykazano, że zjawisko to może skutkować rozległymi uszkodzeniami pęcherzyków płucnych i śródbłonka naczyń płuc u chorych z ciężka postacia COVID-19 (JANIUK i współaut. 2021). Zniszczenie tych ostatnich struktur skutkuje uwolnieniem czynnika von Willebranda (VWF), który odpowiada za aktywację płytek krwi i neutrofili.

Wskutek sztormu cytokinowego w organizmie moga pojawić się liczne uszkodzenia tkanek i narząów. W przypadku łagodnego przebiegu choroby objawami sa m.in.: gorączka, zmęczenie, bóle mięśni i stawów, bóle głowy i wysypka. Natomiast w ciężkich przypadkach pojawiają się m.in.: wysoka goraczka, ostre uszkodzenie płuc, ARDS, zespół rozsianego wykrzepiania wewnątrznaczyniowego (ang. disseminated intravascular coagulation, DIC), zespół ogólnoustrojowej reakcji zapalnej (ang. systemic inflammatory response syndrome, SIRS), sepsa i niewydolność wielonarządowa, a nawet śmierć (TANG i współaut. 2020).

\section{NET A ZABURZONA KOAGULACJA/ZAKRZEPICA W PRZEBIEGU COVID-19}

Powikłania zakrzepowe sa ważna komplikacją w przebiegu COVID-19, a ich nasilenie jest współdecydujace o przebiegu tej choroby. Wykazano, że wśród pacjentów $Z$ COVID-19, koagulopatie, czyli stany nadkrzepliwości, stanowią manifestację kliniczna tej choroby i powoduja nieodwracalne uszkodzenia wielonarzadowe (ACKERMANN i współaut. 2021). Skutki nadmiernej zakrzepicy zwiazane sa przede wszystkim $z$ zablokowaniem dopływu krwi do narządów w organizmie, powodując ich niewydolność, niedotlenienie oraz utratę napięcia naczy-

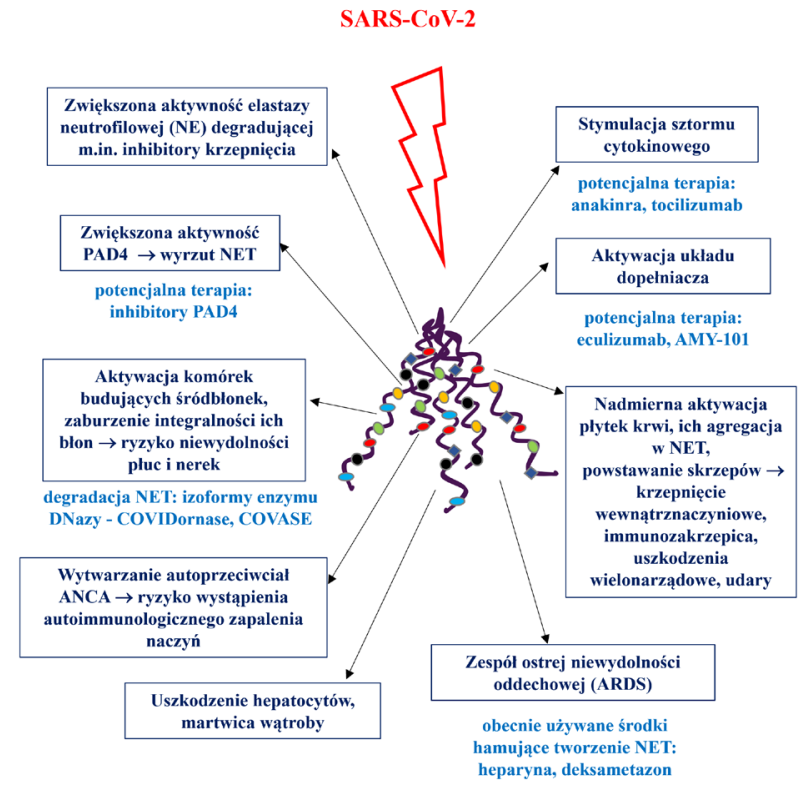

Ryc. 5. Patologiczne efekty nadmiernego tworzenia NET w przebiegu infekcji SARS-CoV-2 w trakcie COVID-19.

Na schemacie przedstawiono szkodliwy udział sieci NET oraz ich składowych w przebiegu COVID-19 (kolor granatowy), a także wymieniono potencjalne terapie jakie stosuje się, testuje lub rozpatruje, w celu zniwelowania skutków tworzenia NET w czasie COVID-19 (kolor jasno niebieski). NET - zewnątrzkomórkowe pułapki neutrofilowe, PAD4 - deiminaza peptydyloargininy 4, ANCA przeciwciała skierowane przeciwko cytoplazmie własnych granulocytów obojętnochłonnych. 
niowego, uniemożliwiając prawidłowy skurcz naczyń krwionośnych.

W przypadku niekontrolowanego rozwoju zakrzepicy może dojść do wystapienia wstrząsu czy nawet sepsy, gdyż w przebiegu COVID-19 dochodzi także do zwiększonej produkcji cytokin prozapalnych $\mathrm{m}$. in.:

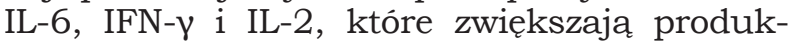
cję i aktywność płytek krwi oraz ekspresję czynnika tkankowego (ang. tissue factor, TF) na komórkach śródbłonka (ACKERMANN i współaut. 2021). Co więcej, poziom IL-8 jest zwiększony w chorobie COVID-19, a chemokina ta odpowiada za przyciaganie neutrofili do miejsca zapalenia i predysponuje te komórki do tworzenia NET (MIDDLETON i współaut. 2020) (Ryc. 5). We wcześniejszych badaniach wykazano także, że ilość powstajacych sieci NET jest istotnie zwiazana $z$ uszkodzeniem wielonarząowym i niezależnie prognozuje rozwój rozsianego krzepnięcia wewnatrznaczyniowego (DIC), a nawet śmiertelność. Zakrzepica u pacjentów z COVID-19 obejmuje zarówno tętniczy, jak i żylny układ krażenia, prowadząc do takich stanów patologicznych i chorób jak: ostry zespół wieńcowy (ang. acute coronary syndrome, ACS), udar mózgu, zakrzepica żył głębokich (DVT), zatorowość płucna czy zakrzepica mikronaczyniowa (ACKERMANN i współaut. 2021). Ponadto, ilość tworzacych się agregatów neutrofili i płytek krwi jest zwiększona w przebiegu COVID-19. Płytki krwi akumulują się na powierzchni neutrofili i pobudzaja neutrofile do wyrzutu NET, a one $z$ kolei powoduja aktywację płytek krwi, ich agregacje i aktywacje trombiny (Glosarium 2). Dodatkowo, już powstałe NET staja się miejscem gromadzenia się erytrocytów, płytek krwi i fibryny, co prowadzi do powstania skrzepów (JANIUK i współaut. 2021). Wszystkie powyższe zjawiska nasilaja krzepnięcie wewnątrznaczyniowe i objawy immunozakrzepicy.

Co ważne, w NET wykryto także obecność czynnika tkankowego TF, będacego induktorem kaskady krzepnięcia (Glosarium 2) oraz wykazano, że aktywny $\mathrm{TF}$ występujący w sieciach sprzyja formowaniu się skrzepu (SKEndRos i współaut. 2020). NET moga także występować w naczyniach krwionosnych w dużych grupach, tworzac agregaty sieci NET (ang. aggregated NETs, aggNETs). Zalegajace w takiej formie w naczyniach NET prowadza do ich zaczopowania, co może skutkować śmiercią, szczególnie w przypadku niedrożności mniejszych naczyń i mikronaczyń (ACKERMANN i współaut. 2021).

Wykazano także, że poziom VWF jest podwyższony w czasie COVID-19, a stężenie czynników regulujacych jego poziom, proteazy ADAMTS13 (ang. a disintegrin and metalloproteinase with a thrombospondin type
1 motif, member 13) i HDL (ang. high density lipoprotein, lipoproteina wysokiej gęstości, tzw. „dobry cholesterol”), jest obniżony (Glosarium 2). W tym kontekście należy wspomnieć o powiązaniu tego zjawiska $z$ grupami krwi i możliwościa, że moga one determinować przebieg COVID-19: wstępne badania wskazuja, że osoby $z$ grupa krwi 0 , które mają fizjologicznie niższy poziom czynnika von Willebranda, charakteryzuje mniejsze ryzyko infekcji i ciężkiego przebiegu tej choroby (MEI i współaut. 2021). Wiele innych czynnikow regulujących kaskadę krzepnięcia jest rozregulowanych w przebiegu infekcji SARS-CoV-2 i choć w niektórych przypadkach zwiększone sa poziomy czynników hamujacych ten proces, np. TFPI, to należy pamiętać, że ich efekty moga być niwelowane przez inne zintensyfikowane procesy. W przypadku TFPI, czynnik ten jest rozkładany przez NE zawarta w NET, a przecież produkcja sieci jest bardzo silna w czasie COVID-19.

Chociaż COVID-19 wiąże się $z$ ciężkim stanem zapalnym, nie wykazano trombocytozy, czyli nadpłytkowości (zwiększonej liczby płytek we krwi) u pacjentów $z$ ta choroba. Wręcz przeciwnie, badania pokazały, że liczba płytek krwi może być zmniejszona u pacjentów z COVID-19. Trombocytopenia, czyli małopłytkowość jest wykrywana u 5-41,7\% pacjentów zainfekowanych SARS-CoV-2, ale aż w 58-95\% ciężkich przypadków COVID-19 (LEVI i współaut. 2020). Przyczyny małopłytkowości moga być różnorodne, ale jedna $z$ nich jest akumulacja płytek w miejscach mikrozakrzepów, które są charakterystyczne dla COVID-19 (ACKERMANN i współaut. 2021). Należy podkreślić, że powstanie NET nie jest jedyna przyczyna nadkrzepliwości/ powstawania skrzeplin i zatorów w trakcie COVID-19. SARS-CoV-2 infekuje także bezpośrednio komórki śródbłonka, powodujac odsłonięcie warstw podśródbłonkowych inicjujacych proces powstawania skrzepów (MARCINKIEWICZ i współaut. 2021).

POWIAZZANIE AKTYWACJI UKŁADU DOPEENIACZA $Z$ TWORZENIEM NET W CZASIE INFEKCJI SARS-CoV-2

Obecne dane wskazuja na powiazanie nadmiernej aktywacji układu dopełniacza przez czasteczki wirusa SARS-CoV-2 z patogeneza i wysoka śmiertelnościa pacjentów zapadajacych na COVID-19 (JAVA i współaut. 2020). Wśród aktywowanych białek wyróżnia się cząsteczkę C3 (wraz z produktami jej aktywacji m.in. C3a, C3b, C3c) (Glosarium 1), proteazę serynowa MASP-2 (ang. mannan-binding lectin-associated serine protease 2) oraz kompleks atakujacy błonę (ang. membrane attack complex, MAC), 
co potwierdza fakt, że inicjacja aktywacji układu dopełniacza w czasie infekcji następuje przez większość dostępnych szlaków (CUGNo i współaut. 2020). Ponadto, w osoczu pacjentów z COVID-19 stwierdzono podwyższony poziom białek C5a i C5b-9, które zwiększaja aktywność neutrofili, a w konsekwencji powoduja postepujacy stan zapalny i uszkodzenia śródbłonka, przyczyniając się do wielonarzadowych zmian chorobowych (JAVA i współaut. 2020). W kontekście powiazania układu dopełniacza $z$ tworzeniem NET w czasie infekcji SARS-CoV-2, stwierdzono silny wpływ aktywacji układu dopełniacza ( $z$ dodatkowym udziałem płytek krwi) na wzmożona chemotaksję neutrofili do płuc, wyrzut NET oraz wystapienie mikrozakrzepów i objawów immunozakrzepicy (Skendros i współaut. 2020). Poza obecnością markerów swoistych dla NET (MPO, citH3), w surowicy pacjentów z COVID-19 obserwowano zwiększony poziom białka C3, czynnika B i P (properdyny), czyli składników niezbędnych do generowania i stabilizacji konwertazy C3, wzmacniajac w ten sposób kaskadowa aktywację układu dopełniacza. Ponadto, aktywacja dopełniacza powiazana ze zwiększonym wyrzutem NET indukuje tworzenie anafilatoksyn (białek C3a, C4a, C5a wywołujacych degranulację komórek tucznych), które dodatkowo wywołuja napływ i aktywację neutrofili, monocytów i eozynofili do zainfekowanej tkanki, a także produkcje cytokin prozapalnych. Zatem, pomimo iż sieci NET sa korzystne w obronie gospodarza przed patogenami, ich nasilone tworzenie przez zaktywowane komórki w przebiegu COVID-19, może wywołać kaskadę reakcji zapalnych, które uszkadzaja i niszcza otaczajace tkanki własne gospodarza (JAVA i współaut. 2020).

\section{POTENCJALNE TERAPIE PRZECIWKO WIRUSOWI SARS-COV-2 SKONCENTROWANE NA NET}

Ponieważ wirus SARS-CoV-2 bezpośrednio wywołuje wyrzut NET przez neutrofile w sposób zależny od dawki, dlatego znalezienie sposobu na efektywne zahamowanie tworzenia NET może okazać się dobra metoda w leczeniu COVID-19. Jeden $z$ mechanizmów wyrzutu NET w trakcie COVID-19 polega na aktywności enzymu PAD4, zatem skutecznym podejściem w terapii tej choroby mogło by być podanie inhibitorów PAD4. Ich pozytywny efekt odnotowano w czasie leczenia letalnej endotoksemii płuc (LIANG i współaut. 2018) i uszkodzeń komórek spowodowanych niedotlenieniem (LANGE i współaut. 2014), chorób w których NET przyczyniają się do rozwoju patologii (ACKERMANN i współaut.
2021). Ponadto wiadomo już, że w czasie infekcji wirusem SARS-CoV-2 płytki krwi moga ulec aktywacji (HOTTz i współaut. 2020), a ich interakcja $z$ neutrofilami może doprowadzić do wyrzutu NET, jednak jak dotąd nie udało się ustalić precyzyjnego mechanizmu tego procesu, dlatego w tym przypadku nie wskazano jeszcze możliwych środków leczniczych (MCDONALD i współaut. 2017, ACKERMANN i współaut. 2021).

Skutki tworzenia NET w COVID-19 obserwuje się na poziomie komórek i narządów w kilku aspektach. Jednym $z$ enzymów proteolitycznych stanowiących część NET jest elastaza neutrofilowa, która, oprócz uszkodzeń tkanek własnych organizmu, może sprzyjać infekcji komórek gospodarza przez wirusa, jak opisano to powyżej (ACKERMANN i współaut. 2021). Naturalnym podejściem byłoby zatem wykorzystanie inhibitora elastazy neutrofilowej, np. endogennej alfa1-antytrypsyny (AAT), jednak endogenna elastaza pochodzaca $z$ NET opiera się działaniu wymienionego inhibitora, co stwarza problem w leczeniu COVID-19 (LEPPKES i współaut. 2020). Wykazano bowiem, że w surowicy pacjentów z COVID-19 aktywność NE jest bardzo wysoka mimo obecności alfa1-antytrypsyny. Co jednak ciekawe, kiedy surowicę pacjentów z COVID-19, zawierajaca AAT, dodano do egzogennej NE (nie pochodzącej $z$ organizmu pacjentów), doszło do zahamowania jej aktywności. A zatem wyniki te sugeruja, że obecna u chorych NE jest, przynajmniej częściowo, oporna na ten inhibitor. Jedna $z$ możliwych przyczyn jest fakt, że NE pacjentów jest zwiazana $z$ DNA (jako część NET), co powoduje zablokowanie miejsca wiazania inhibitora (LEPPKES i współaut. 2020).

NET i produkty ich degradacji sa również odpowiedzialne za uszkodzenia komórek naczyń krwionośnych, czego efektem może być wytworzenie w organizmie autoprzeciwciał, których obecność prowadzi do pojawienia się autoimmunologicznego zapalenia naczyń (ACKERMANN i współaut. 2021). Możemy zaobserwować tu analogię do SVV, gdzie przeciwko białkom występujacym na powierzchni NET wytwarzane sa autoprzeciwciała ANCA, które wykazuja wysokie powinowactwo w stosunku do MPO i proteinazy 3 (YoshIDA i współaut. 2013). ANCA pobudzaja neutrofile do wyrzutu NET zgodnie $z$ mechanizmem sprzężenia zwrotnego dodatniego oraz pośrednio promuja powstanie stanów zapalnych w obrębie naczyń krwionośnych (Chen i KAllenberg 2009). Ponadto, interakcja NET i śródbłonka naczyniowego skutkuje aktywacja i apoptoza komórek wchodzacych $\mathrm{w}$ jego skład, co w rezultacie doprowadza do zniszczenia jego integralności i utracenia 
zdolności do pełnienia funkcji $\mathrm{w}$ organizmie. Uszkodzenie śródbłonka naczyniowego, wywołanego przez NET lub bezpośrednio, wskazuje się jako główna przyczynę niewydolności płuc i nerek w COVID-19 (ACKERMANN i współaut. 2021). Dodatkowo, zainfekowane komórki śródbłonka wydzielaja różnorodne zwiazki o działaniu parakrynnym (miejscowym), które wpływaja na funkcjonowanie samego endotelium, jak i pobliskich komórek, takich jak pneumocyty i neutrofile, oraz moga przyczynić się do rekrutacji limfocytów $\mathrm{T} \mathrm{w}$ miejsce infekcji (ACKERMANN i współaut. 2021). NET wyrzucane przez neutrofile zrekrutowane do płuc moga uczestniczyć w wystapieniu immunozakrzepicy i ARDS, które odpowiadaja za uszkodzenia tego organu w czasie ciężkiego przebiegu COVID-19 (ACKERMANN i współaut. 2021). Przy ciężkim zakażeniu wirusem SARS-CoV-2 często, choć nie zawsze, obserwowane sa uszkodzenia wątroby lub nawet jej martwica, która może wystapić na skutek aktywności samego wirusa i/lub zniszczeń wynikajacych $z$ obecności w organizmie nadmiernej ilości cytokin i NET (ACKERMANN i współaut. 2021). W tym procesie zaobserwować można podobieństwa do przebiegu sepsy, kiedy neutrofile gromadza sie m.in. w watrobie, a następnie wyrzucaja duże ilości NET (KoLACZKOWSKA i współaut. 2015), które wspomagaja komórki Browicza-Kupffera (makrofagi watroby) w wychwytywaniu bakterii obecnych we krwi (MCDONALD i współaut. 2012). Same neutrofile i wyrzucone przez nie struktury pozostaja jednak w naczyniach wattroby na długo po wyeliminowaniu przyczyny infekcji, przyczyniając się do degradacji śródbłonka naczyniowego i hepatocytów (KolACZKOWSKA i współaut. 2015). Przyczyny zaburzeń w usuwaniu NET nie sa dotychczas poznane, ale wiadomo, że zaburzone mechanizmy tego procesu przyczyniaja się do rozwoju i/lub patologii licznych chorób autoimmunizacyjnych, nowotworowych czy sepsy (SANTOCKI i KOLACZKOWSKA 2020).

Środki, którymi obecnie próbuje się hamować tworzenie NET u pacjentów $z$ COVID-19, to najczęściej przeciwzapalny deksametazon i przeciwzakrzepowa heparyna (ACKERMANN i współaut. 2021). Deksametazon, który jest glikokortykoidem, działa poprzez zmniejszanie wydzielania mediatorów prozapalnych $\mathrm{w}$ organizmie chorego, w efekcie ograniczajac wyrzut NET przez neutrofile (ACKERMANN i współaut. 2021). Heparyna natomiast działa neutralizujaco na histony, majac do nich wysokie powinowactwo, powoduje ich odłączenie się od DNA wchodzacego w skład NET (FUCHS i współaut. 2010). Heparyna dodatkowo współdziała $z$ enzymem DNaza I w rozkładaniu powstałych skrzepów, gdyż rozkłada „szkielet” NET (LEPPKES i współaut. 2020). U niektórych pacjentów może pojawić się jednak oporność na heparynę, co stanowi problem w wykorzystaniu jej jako leku (ACKERMANN i współaut. 2021). Jako że cytokiny prozapalne odgrywaja ogromna rolę $\mathrm{w}$ patologii COVID-19, obecnie testuje się kilka preparatów będących głównie przeciwciałami monoklonalnymi (ang. monoclonal antibody, $\mathrm{mAb}$; neutralizuja one docelowe białko), np. tocilizumab hamujacy działanie IL-6 czy anakinra (rekombinowany antagonista receptora dla IL-1, IL-1Ra) blokująca IL-1a i IL-1 $\beta$. Oba te leki, po przejściu badań klinicznych, mogłyby być używane także w terapii anty-SARS-CoV-2 (ACKERMANN i współaut. 2021).

Jako preparaty lecznicze w przebiegu COVID-19 wdraża się również leki, których działanie opiera się na hamowaniu układu dopełniacza. Sa to np. eculizumab i AMY101, których używa się $z$ powodzeniem w trakcie leczenia niewielkiego odsetka pacjentów bardzo ciężko przechodzacych COVID-19 (LAURENCE i współaut. 2020, MASTAGLio i współaut. 2020). Eculizumab to humanizowane $\mathrm{mAb}$ anty-C5, natomiast AMY-101 to mały peptyd, który wiąże składnik C3 i nie dopuszcza do jego aktywacji (MASTELlos i współaut. 2020). Badania kliniczne dowodza skuteczności obu środków w leczeniu ARDS spowodowanego infekcja SARS-CoV-2, z przewaga AMY-101 nad eculizumabem (MASTELLOS i współaut. 2020). Należy jednak zaznaczyć, że terapie oparte o mAb są bardzo drogie.

Jako potencjalne leki rozważa się również różne izoformy enzymu DNazy (np. COVIDornase, COVASE), hydrolizujacego DNA, z którego składa się NET. Należy tu jednak podkreślić, że DNaza nie doprowadza do kompletnej degradacji NET, pozostawiajac w organizmie ich małe fragmenty, które wciąz moga promować stan zapalny (KoLACZKOWSKA i współaut. 2015). Wszystkie testowane środki, które mogłyby być potencjalnie wykorzystane w leczeniu COVID-19 będa w przyszłości porównywane w swojej skuteczności względem dotychczas stosowanych - deksametazonu i heparyny, które obecnie pełnia rolę standardu (ACKERMANN i współaut. 2021). Jednak docelowo, w przypadku NET wydaje się, że najwłaściwszym podejściem jest strategia leczenia opierająca się zarówno na hamowaniu powstawania NET, jak i wspomagająca degradację tych NET, które już powstały (ACKERMANN i współaut. 2021). Problem polega jednak na tym, że obecnie nie istnieja selektywne inhibitory tworzenia NET, a spośród tych istniejących, częściowo blokujących ścieżki inicjujące powstawanie sieci (np. Cl-amidine) żaden nie jest dopusz- 
czony do stosowania u ludzi, z wyjątkiem terapii eksperymentalnych.

\section{PODSUMOWANIE}

Do roku 2020 r. pandemia była pojęciem znajdowanym w podręcznikach immunologii, a poprzednia światowa epidemia rozpoczęła się 102 lata wcześniej (była spowodowana tzw. grypa hiszpanka) i skończyła się po 3 latach. Należy mieć nadzieję, że pandemia COVID-19 będzie trwała krócej, m.in. ze względu na fakt, że rozumiemy coraz więcej $z$ jej mechanizmów oraz już stworzyliśmy skuteczne szczepionki. Jednak z drugiej strony, skala podróżowania jest niewspółmiernie zwiększona od tamtego czasu, a wyszczepialność nie jest wystarczająca. Jedna $z$ przyczyn zjawisk patologicznych zachodzących w czasie infekcji SARS-CoV-2 jest powstanie nadmiernej ilości nieusuwanych NET, które bezpośrednio lub wtórnie prowadza do uszkodzeń tkanek, procesów zakrzepowych, sztormu cytokinowego i aktywacji układu dopełniacza. Nadmierna aktywacja reakcji odpornościowych jest bronia obosieczna i często właśnie to zjawisko, a nie sam czynnik infekujacy, powoduje ciężki przebieg choroby lub nawet śmierć. Jednak znajac mechanizmy patofizjologiczne jesteśmy w stanie stworzyć nowe terapie, których rozwój w kontekście NET omawiamy w niniejszej pracy.

\section{Streszczenie}

Choroba COVID-19 wywołana przez wirusa SARS-CoV-2 powoduje poważne uszkodzenia płuc, ale także innych narządów w organizmie człowieka. Infekcja może spowodować bardzo silna aktywację odpowiedzi immunologicznej, zwłaszcza wrodzonej, prowadząc m.in. do nadmiernej aktywacji neutrofili. Komórki te, stanowiace liczebnie największa populację leukocytów we krwi człowieka, po silnej aktywacji moga wyrzucać tzw. zewnątrzkomórkowe sieci neutrofilowe NET. Struktury te maja na celu wyłapywanie i unieruchamianie (ograniczając infekcję) patogenów takich jak bakterie i wirusy. Jednak ze względu na fakt, że w ich skład wchodza białka i kwasy nukleinowe silnie cytotoksyczne oraz aktywujace kaskadę krzepnięcia i układ dopełniacza, uszkodzeniu moga ulegać także tkanki własne organizmu. W artykule przedstawiamy budowę, funkcje i efekty uboczne tworzenia NET w organizmie człowieka, a przede wszystkim opisujemy obecny stan wiedzy dotyczacy wpływu NET na przebieg COVID-19. NET sa silnie indukowane przez SARS-CoV-2, prowadząc do procesów patologicznych $\mathrm{w}$ trakcie COVID-19, w tym uszkodzeń wielonarządowych, m.in. zwiąanych $z$ tworzeniem zakrzepów. Przedstawiamy także testowane oraz potencjalne, terapie anty-NET mogace poprawić stan chorych i/lub ochronić przed śmiercia.

\section{LITERATURA}

ACKermann M., ANDERS H. J., Bilyy R., Bowlin G. L., Daniel C., Lorenzo R. De, Egeblad M. i współaut., 2021. Patients with COVID-19: in the dark-NETs of neutrophils. Cell Death Differ., doi.org/10.1038/s41418-021-00805-z.

BOElTZ S., AMINI P., ANDERS H. J., ANDRADE F., BILYY R., CHATFIELD S., CICHON I. i współaut., 2019. To NET or not to NET:current opinions and state of the science regarding the formation of neutrophil extracellular traps. Cell Death Differ. 26, 395-408.

BORREGAARD N., 2010. Neutrophils, from marrow to microbes. Immunity. 33, 657-670.

BRINKMANN V., ZYCHLINSKY A., 2012. Neutrophil extracellular traps: is immunity the second function of chromatin? J. Cell Biol. 19, 87738783.

BrinkmanN V., REICHARD U., GoOSMANn C., FAULER B., UHLEMANN Y., WeISS D. S., WEINRAUCH Y., ZYCHLINSKY A., 2004. Neutrophil extracellular traps kill bacteria. Science 303, 15321535.

Chen M., Kallenberg C. G. M., 2009. New advances in the pathogenesis of ANCA-associated vasculitides. Clin. Exp. Rheumatol. 27, 108-114.

Cugno M., Meroni P. L., Gualtierotti R., GrifFini S., GRovetTi E., TORRI A., PANIGADA M. i współaut. 2020. Complement activation in patients with COVID-19: A novel therapeutic target. J. Allergy Clin. Immunol. 146, 215-217.

FARRERA C., FADEEL B., 2013. Macrophage clearance of neutrophil extracellular traps is a silent process. J. Immunol. 191, 2647-2656.

FouserT E., TOES R., DESAI J., 2020. Neutrophil extracellular traps (NETs) take the central stage in driving autoimmune responses. Cells 9, doi.org/10.1371/journal.pone.0097088.

Fuchs T. A., BRILl A., DuERSCHMIED D., SCHATZBERG D., MONEsTier M., MYers D. D., WrOBLESKI S. K. i współaut. 2010. Extracellular DNA traps promote thrombosis. Proc. Natl. Acad. Sci. USA 107, 15880-15885.

Golab J., JAKOBISIAK M., LASEK W., STOKŁosa T., 2017. Immunologia. PWN, Warszawa.

GuO Y. R., CAO Q. D., HONG Z. S., TAN Y. Y., CHEN S. D., JIN H. J., TAN K. i współaut., 2020. The origin, transmission and clinical therapies on coronavirus disease 2019 (COVID-19) outbreak - an update on the status. Mil. Med. Res. 7, doi.org/10.1186/s40779020-00240-0.

Gupta A. K., Giaglis S., Hasler P., Hahn S., 2014. Efficient neutrophil extracellular trap induction requires mobilization of both intracellular and extracellular calcium pools and is modulated by cyclosporine A. PLoS One 9, doi. org/10.1371/journal.pone.0097088.

HoffmanN M., Kleine-Weber H., Schroeder S., KRÜGER N., HERRLER T., ERICHSEN S., SCHIERGENS T. S. i współaut., 2020. SARS-CoV-2 cell entry depends on ACE2 and TMPRSS2 and is blocked by a clinically proven protease inhibitor. Cell 181, 271-280.

HotTz E. D., AzEvedo-Quintanilha I. G., Palhinha L., Teixeira L., Barreto E. A., PÃo C. R. R., RIGHY C. i współaut., 2020. Platelet activation and platelet-monocyte aggregate formation trigger tissue factor expression in patients with severe COVID-19. Blood 136, 1330-1341.

HU J., HE C. L., GaO Q. Z., ZHANG G. J., CAO X. X., LONG Q. X., DENG H. J. i współaut., 2020. D614G mutation of SARS-CoV-2 spike protein enhances viral infectivity. bioRxiv, doi. org/10.1101/2020.06.20.161323.

HuANG Y., YANG C., XU X.-F., XU W., LiU S.-W., 2020. Structural and functional properties of SARS-CoV-2 spike protein: potential antivirus 
drug development for COVID-19. Acta Pharmacol. Sin. 41, 1141-1149.

JANIUK K., JABŁońSKA E., GARLEY M., 2021. Significance of NETs formation in COVID-19. Cells 10, doi.org/10.3390/cells 10010151 .

JAVA A., APICELLI A. J., KATHRYN LISZEWSKI M., Coler-Reilly A., AtKinson J. P., KIM A. H. J., KULKARNI H. S., 2020. The complement system in COVID-19: friend and foe? JCI Insight 5, doi.org/10.1172/jci.insight.140711.

KAPLAN M. J., RADIC M., 2012. Neutrophil extracellular traps: double-edged swords of innate immunity. J. Immunol. 189, 2689-2695.

KHANDPUR R., CARMONA-RIVERA C., VIVEKANANDAN-GiRI A., Gizinski A., Yalavarthi S., KNIGHT J. S., FRIDAY S. i współaut., 2013. NETs are a source of citrullinated autoantigens and stimulate inflammatory responses in rheumatoid arthritis. Sci. Transl. Med. 5, doi.org/10.1126/ scitranslmed.3005580.

KolaczKOWSKA E., KUBES P., 2013. Neutrophil recruitment and function in health and inflammation. Nat. Rev. Immunol. 13, 159-175.

KolaczKowska E., Lelito M., KozaKiewiCZ E., RoOIJEN N. VAN, PLYTYCZ B., ARNOLD B., 2007. Resident peritoneal leukocytes are important sources of MMP-9 during zymosan peritonitis: superior contribution of macrophages over mast cells. Immunol. Lett. 113, 99-106.

KolaczKOWSKa E., JenNe C. N., SuREWAARD B. G. J., Thanabalasuriar A., LeE W. Y., SANZ M. J., MoweN K. i współaut., 2015. Molecular mechanisms of NET formation and degradation revealed by intravital imaging in the liver vasculature. Nat. Commun. 6, doi.org/10.1038/ ncomms7673.

Kumar Y., Bhatia A., Minz R. W., 2009. Antinuclear antibodies and their detection methods in diagnosis of connective tissue diseases: a journey revisited. Diagn. Pathol. 4, doi. org/10.1186/1746-1596-4-1

LANGE S., Rocha-FERREIRA E., THei L., MAWJEe P., BENNETT K., THOMPSON P. R., SUBRAMANIAN V. i współaut., 2014. Peptidylarginine deiminases: novel drug targets for prevention of neuronal damage following hypoxic ischemic insult (HI) in neonates. J. Neurochem. 130, $555-562$.

Laurence J., Mulvey J. J., Seshadri M., RacaNELLI A., HARP J., SCHENCK E. J., ZAPPETTI D. i współaut., 2020. Anti-complement C5 therapy with eculizumab in three cases of critical COVID-19. Clin. Immunol. 219, doi.org/10.1016/j.clim.2020.108555.

LEPPKES M., KNOPF J., NASCHBERGER E., LINDEMANN A., Singh J., HerRmann I., STÜRZl M. i współaut., 2020. Vascular occlusion by neutrophil extracellular traps in COVID-19. EBioMedicine 58, doi.org/10.1016/j.ebiom.2020.102925.

LEVI M., THACHIL J., IBA T., LEVY J. H., 2020. Coagulation abnormalities and thrombosis in patients with COVID-19. Lancet Haematol. 7, doi.org/10.1016/S2352-3026(20)30145-9.

Li Y., ZHOU W., YANG L., YOU R., 2020. Physiological and pathological regulation of ACE2, the SARS-CoV-2 receptor. Pharmacol. Res. 157, doi.org/10.1016/j.phrs.2020.104833.

Liang Y., Pan B., Alam H. B., Deng Q., Wang Y., CHEN E., LIU B. i współaut., 2018. Inhibition of peptidylarginine deiminase alleviates LPS-induced pulmonary dysfunction and improves survival in a mouse model of lethal endotoxemia. Eur. J. Pharmacol. 833, 432-440.

Manley H. R., Keightley M. C., LieschKe G. J., 2018. The neutrophil nucleus: An important influence on neutrophil migration and func- tion. Front. Immunol. 9, doi.org/10.3389/fimmu.2018.02867.

MARCINKIEWICZ J., WITKOWSKI J. M., OLSZANECKI $\mathrm{R} ., 2021$. The dual role of the immune system in the course of COVID-19. the fatal impact of the aging immune system. Cent. Eur. J. Immunol. 46, 1-9.

Mastaglio S., Ruggeri A., Risitano A. M., Angelillo P., Yancopoulou D., Mastellos D. C., HUBER-LANG M. i współaut., 2020. The first case of COVID-19 treated with the complement C3 inhibitor $A M Y-101$. Clin. Immunol. 215, doi.org/10.1016/j.clim.2020.108450.

Mastellos D. C., PIRES DA Silva B. G. P., FonseCA B. A. L., FonseCA N. P., AuXiliadora-MARTINS M., Mastaglio S., RUGGeri A. i współaut., 2020. Complement C3 vs C5 inhibition in severe COVID-19: Early clinical findings reveal differential biological efficacy. Clin. Immunol. 220, doi.org/10.1016/j.clim.2020.108598.

McDonald B., URRUtia R., YipP B. G., Jenne C. N., KuBES P., 2012. Intravascular neutrophil extracellular traps capture bacteria from the bloodstream during sepsis. Cell Host Microbe 12, 324-333.

MCDONALD B., Davis R. P., KIM S. J., TSE M., ESMON C. T., KOlaCZKOWSKA E., JENNE C. N., 2017. Platelets and neutrophil extracellular traps collaborate to promote intravascular coagulation during sepsis in mice. Blood 129, 1357-1367.

Meher A. K., Spinosa M., Davis J. P., Pope N., Laubach V. E., Su G., Serbulea V. i wspó1aut., 2018. Novel role of IL (Interleukin)-1ß in neutrophil extracellular trap formation and abdominal aortic aneurysms. Arterioscler. Thromb. Vasc. Biol. 38, 843-853.

MEI Z. W., WIJK X. M .R. VAN, PHAM H. P., MARIN M. J., 2021. Role of von Willebrand factor in COVID-19 associated coagulopathy. J. Appl. Lab. Med., doi.org/10.1093/jalm/jfab042.

MidDleton E. A., HE X. Y., DENORME F., CAMPBell R. A., NG D., SAlvatore S. P., Mostyka M. i współaut., 2020. Neutrophil extracellular traps contribute to immunothrombosis in $\mathrm{CO}$ VID-19 acute respiratory distress syndrome. Blood 136, 1169-1179.

Papayannopoulos V., MetzleR K. D., HaKkim A., ZYCHLINSKY A., 2010. Neutrophil elastase and myeloperoxidase regulate the formation of neutrophil extracellular traps. J. Cell Biol. 191, 677-691.

SANTOCKI M., KOŁACZKOWSKA E., 2017. Wyrzut zewnattrzkomórkowych sieci neutrofilowych (NET) przez neutrofile i co dalej? Konsekwencje tworzenia $i$ nieprawidłowego usuwania NET. Kosmos 66, 623-634.

SANTOCKI M., KOLACZKOWSKA E., 2020. On neutrophil extracellular trap (NET) removal: What we know thus far and why so little. Cells. 9, doi. org/10.3390/cells9092079.

SKENDROS P., Mitsios A., Chrysanthopoulou A., Mastellos D. C., Metallidis S., RafailiDIS P., NTINOPOULOU M. i współaut., 2020. Complement and tissue factor-enriched neutrophil extracellular traps are key drivers in COVID-19 immunothrombosis. J. Clin. Invest. 130, 6151-6157.

SKopelJA-Gardner S., Jones J. D., Rigby W. F. C., 2018. "NETtling" the host: Breaking of tolerance in chronic inflammation and chronic infection. J. Autoimmun. 88, 1-10.

Song P., LI W., XIE J., Hou Y., YOU C., 2020. Cytokine storm induced by SARS-CoV-2. Clin. Chim. Acta. 509, 280-287. 
Sorvillo N., Cherpokova D., MARTinod K., WAGNER D. D., 2019. Extracellular DNA NET-works with dire consequences for health. Circ. Res. 125, 470-488.

Summers C., Rankin S. M., Condliffe A. M., Singh N., PETERS A. M., ChILVERS E. R., 2010. Neutrophil kinetics in health and disease. Trends Immunol. 31, 318-324.

TANG L., YIN Z., HU Y., MEI H., 2020. Controlling cytokine storm is vital in COVID-19. Front. Immunol. 11, doi.org/10.3389/fimmu.2020.570993.

Veras F. P., Pontelli M. C., Silva C. M., Toller-Kawahisa J. E., Lima M. DE, Nascimento D. C., SCHNEIDER A. H. i współaut., 2020. SARS-CoV-2-triggered neutrophil extracellular traps mediate COVID-19 pathology. J. Exp. Med. 217, doi.org/10.1084/jem.20201129.

VossenaAR E. R., ZENDMAN A. J. W., VenRooiJ W. J. VAN, PRUIJN G. J. M., 2003. PAD, a growing family of citrullinating enzymes: genes, features and involvement in disease. BioEssays. 25, 1106-1118.

WANG Y., Li M., Stadler S., Correll S., Li P., WANG D., HAYAMA R. i współaut., 2009. Histo- ne hypercitrullination mediates chromatin decondensation and neutrophil extracellular trap formation. J. Cell Biol. 184, 205-213.

WITKO-SARSAT V., DESCAMPS-LATSCHA B., 1994. Neutrophil-derived oxidants and proteinases as immunomodulatory mediators in inflammation. Mediators Inflamm. 3, 257-273.

YIPP B. G., KuBES P., 2013. NETosis: how vital is it? Blood 122, 2784-2794.

YoshIDA M., SASAKI M., SUgISAKI K., YAMAGUCHI Y., YAMADA M., 2013. Neutrophil extracellular trap components in fibrinoid necrosis of the kidney with myeloperoxidase-ANCA-associated vasculitis. Clin. Kidney J. 6, 308-312.

Yousefi S., Mihalache C., Kozlowski E., SCHMid I., SimON H. U., 2009. Viable neutrophils release mitochondrial DNA to form neutrophil extracellular traps. Cell Death Differ. 16, 1438-1444.

ZuO Y., YALAVARTHI S., SHI H., GOCKMAN K., ZUO M., MADISON J. A., BLAIR C. i współaut., 2020. Neutrophil extracellular traps in COVID-19. JCI Insight 5, doi.org/10.1172/jci.insight. 138999.

KOSMOS Vol. 70, 3, 419-435, 2021

Justyna Starzyk, Anna Such, Dominika Drab, ElżBieta Kolaczkowska

Pracownia Hematologii Eksperymentalnej, Instytut Zoologii i Badań Biomedycznych, Uniwersytet Jagielloński, Gronostajowa 9, 30-387 Kraków

SARS-CoV-2 VERSUS NEUTROPHILS: ENTRAPPED BY NEUTROPHIL EXTRACELLULAR TRAPS (NETS)

$$
\text { Summary }
$$

Coronavirus disease COVID-19 is induced by SARS-CoV-2 virus leading to severe lung injury, but also other vital organs can be affected in its course. The infection can induce profound activation of the immune system, especially the innate response, leading to over-activation of leukocytes, including neutrophils. The latter cells are the most abundant type of white blood cells in humans, and they can release neutrophil extracellular traps (NETs) when strongly activated. NETs capture and immobilize pathogens such as bacteria and viruses, limiting their spread throughout the body. However, as they consist of cytotoxic proteins and nucleic acids which can also activate coagulation leading to thrombosis, also bystander host cells/organs can get injured. In the article we characterize NETs in terms of their structure, functions and side effects of their formation, but foremost we focus on up-to-date findings on NET involvement in COVID-19. NETs are strongly induced upon SARS-CoV-2 infection, and they cause numerous pathologies during COVID-19 which include multi-organ damage related to thrombosis. We also describe and discuss tested and potential therapies directed against NETs that can improve the condition of patients in the course of the disease and/or prevent mortality. 